Review

\title{
Review of Hybrid Fiber Based Composites with Nano Particles-Material Properties and Applications
}

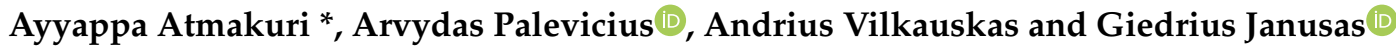 \\ Faculty of Mechanical Engineering and Design, Kaunas University of Technology, Studentu 56, \\ 51424 Kaunas, Lithuania; arvydas.palevicius@ktu.lt (A.P.); andrius.vilkauskas@ktu.lt (A.V.); \\ giedrius.janusas@ktu.lt (G.J.) \\ * Correspondence: ayyappa.atmakuri@ktu.edu
}

Received: 28 August 2020; Accepted: 12 September 2020; Published: 14 September 2020

check for updates

\begin{abstract}
The present review article provides an overview of the properties of various natural and synthetic fibers for the fabrication of pure natural composites and the combination of both natural/synthetic fibers-based hybrid composites, bio-based resins, various fabrication techniques, chemical and mechanical properties of fibers, the effect of chemical treatment and the influence of nanoparticles on the composite materials. Natural fibers are becoming more popular and attractive to researchers, with satisfactory results, due to their availability, ease of fabrication, cost-effectiveness, biodegradable nature and being environmentally friendly. Hybrid composites made up of two different natural fibers under the same matrix material are more popular than a combination of natural and synthetic fibers. Recent studies relevant to natural fiber hybrid composites have stated that, due to their biodegradability and the strength of individual fibers causing an impact on mechanical properties, flame retardancy and moisture absorption, natural fibers need an additional treatment like chemical treatment for the fibers to overcome those drawbacks and to enhance their better properties. The result of chemical treatment on composite material properties such as thermal, mechanical and moisture properties was studied. Researchers found that the positive influence on overall strength by placing the filler materials (nanoparticles) in the composite materials. Hybrid composites are one of the fields in polymer science that are attracting consideration for various lightweight applications in a wide range of industries such as automobile, construction, shipping, aviation, sports equipment, electronics, hardware and biomedical sectors.
\end{abstract}

Keywords: natural and synthetic fibers; hybrid composites; thermosets and thermoplastic resins; fabrication techniques; chemical treatment; nanoparticles; applications

\section{Introduction}

In recent years, many researchers have been showing an interest in the utilization of natural fibers for the preparation of hybrid composites because of its abundance, low density, recyclability and great strength [1,2], Natural fibers received a great deal of consideration as a potential elective alternative for synthetic fibers [3] as a support of different reinforcement for innovative applications due to their properties, for example, their availability in nature, low cost and they are environmentally friendly. Their resources do not emit any harm full gasses and absorb carbon dioxide, which reduces environmental pollution [4-6].

One of the primary drawbacks of using natural fibers as reinforcement in composites is the hydrophilic in nature, which makes them inconsistent with hydrophobic matrices. For refining the inconsistency, the surface treatment of natural fiber is required to advance the global properties of the composite $[7,8]$. Apart from this, natural fibers are readily accessible to the flame, to overcome this drawback, various fire retardants have been added to them to advance its fire resistance. 
Surface modifications by using various chemical compounds tend to increase their mechanical and physical properties. And also, structure modification of the composite materials leads to extra stability $[9,10]$.

Over the previous years, there has been an ever-expanding enthusiasm to fuse at least two fillers into a typical matrix. There has been a consistent increment in the quantity of distributed works that are identified with hybrid composites from the past ten years. in view of hybrid composites (between 2010 to 2020) found in the Web of Science and Scopus via looking for the words 'hybrid composites' with 26,450 research yields. The development came about because of one goal, to progress the properties of the subsequent composite material to accomplish the wanted properties and improved execution of such composites.

Figure 1 shows the total research outcomes on hybrid composites in recent years and the input was from the Web of Science. Most of the research articles are from China, followed by India. The hybridization process intersects the most research articles, for example; material multi-disciplinary, chemical industry, polymeric science, nanoscience, nanotechnology, material science engineering, electrochemistry, mechanics and mechanical engineering so on.

\section{Hybrid Composites}

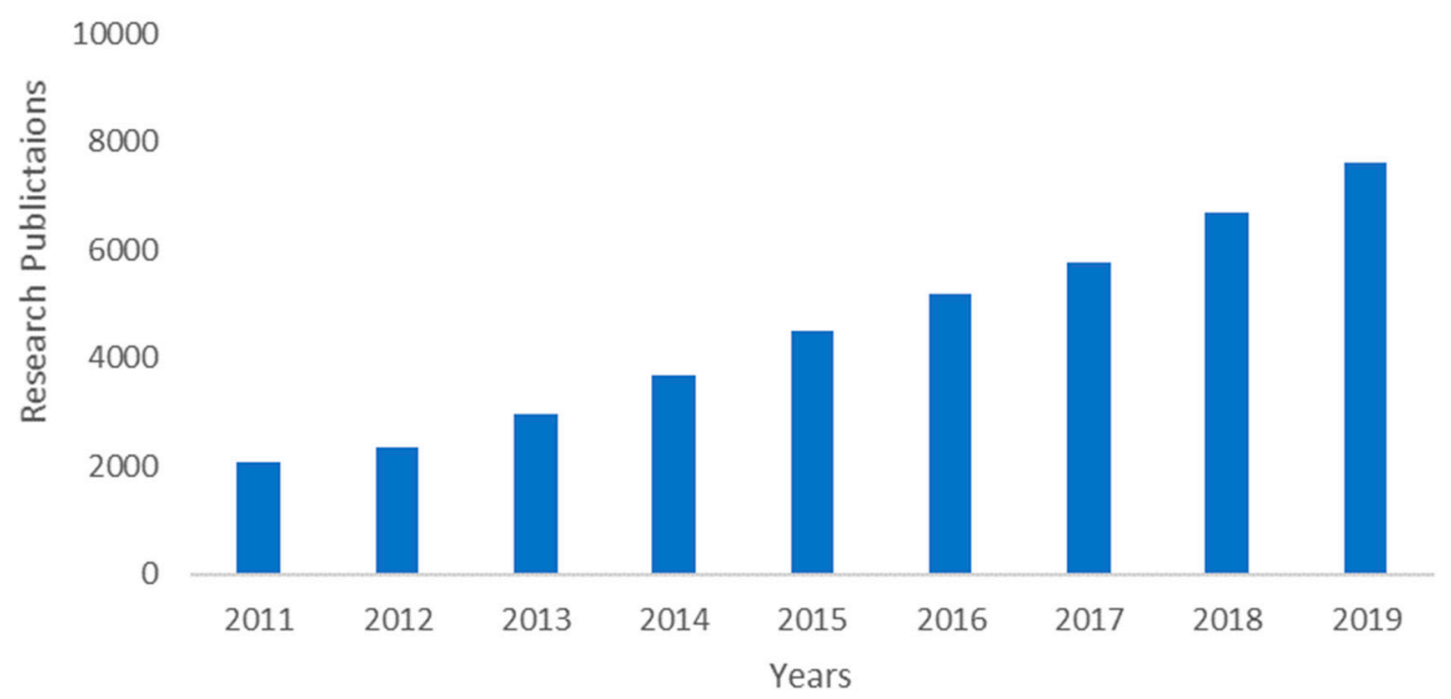

Figure 1. Recent publications on hybrid composites.

Figure 2 shows the total research publications on natural fiber hybrid composites. The input was from the Web of Science by searching for "natural fibers and hybrid composites." There is a total of 1460 research yields, with most of the researchers from material science and polymeric science engineering. The process of the hybridization of natural fiber composites started in early 2008 and then the interest slightly increased. The main aim is to improve the composite properties by adding two or three different filler materials under the same matrix material. Many researchers proved that the orientation of filler material also plays a key role in the composite [11-13].

Hybrid Composites are the materials that are made up of twofold or more constituent materials, namely matrix and reinforcement $[14,15]$. A matrix is a coupling material which binds the reinforcement. Reinforcements are the materials which are embedded in the matrix. These give the additional strength to the composite. The significance of the composites is to provide the desired physical, chemical and mechanical properties in an improved manner, which differs from the individual constituents [16]. Based on the matrix, composites are categorized as polymer, ceramic and polymer. Depending upon the reinforcement these are varied as laminate, fibrous and particulate composites. Depending upon the type of availability, reinforcements are classified as either natural or synthetic [15,17]. 
If the compound material is metal fiber then it is called a metal matrix composite, if it is a polymer matrix then it is called a polymer matrix material $[17,18]$. The fiber reinforced polymers (FRP) consist of a polymer matrix and high-quality fibers joined with an unmistakable crossing point among them. In this shape, the two matrices and fibers hold their chemical and physical properties.

\section{Natural fibre Hybrid composites}

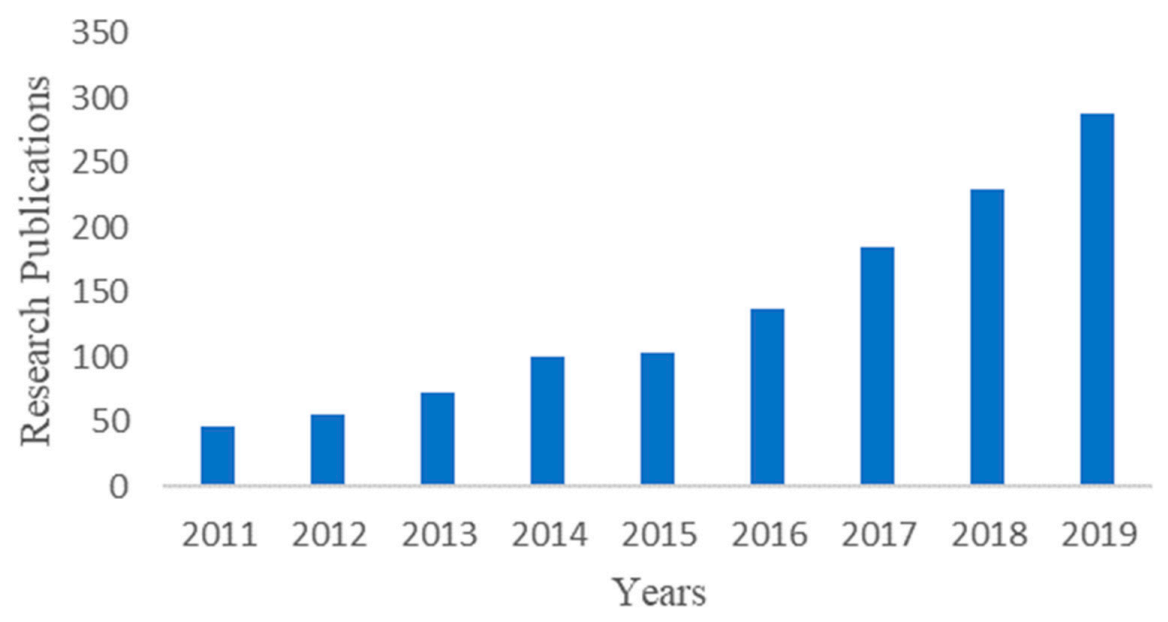

Figure 2. Recent publications on natural fiber hybrid composites.

\section{Natural Hybrid Fiber Composites}

Natural hybrid composite materials contained fibers of great quality and a modulus introduced in a matrix material. Along these lines, every one of the individual materials (fiber and matrix) holds its chemical and physical properties and they give a combination of properties which would not be conceivable if they were utilized alone. Here, the fibers act as the central load-carrying agents and the matrix material encompasses them in position alongside, acting as a load carrying part between them, protecting the fibers from the natural harms of raised temperature and humidity. Accordingly, it could be properly said that the fiber gives reinforcements to the matrix; thus, the name Fiber Reinforced Composite Materials (FRCM).

Reinforced hybrid materials are made by joining at least two distinct varieties of fibers in a distinctive matrix material. Hybridization of two sorts of filaments with particular lengths and widths offers a couple of central focuses over the use of both of the strands alone in a lone polymer lattice. Most studies are on the hybridization of regular filaments with glass strands to upgrade the properties. They have average calorific regard and cause little stress, similar to prosperity, wellbeing and protecting Also, they show amazing mechanical properties, have a low thickness and are modest $[7,14,19-21]$. The benefits of composite materials by confessional materials, such as greater rigidity and durability, make them more flexible to use. The availability and cost of these natural fibers attract researchers and also have promising results of composite fabrication for real-life applications. Composite materials are comprised of at least two materials with physically detachable phases.

\subsection{Characterization of Composites}

Composite materials classified on the basis of a matrix serve as a binder and a reinforcement, which acts as a filler material. Figure 3 shows the classification of composites.

\subsection{Metal Matrix Composites (MMCs)}

Metal matrix composites (MMCs) have numerous advantages over solid metals such as great strength, modulus and better-quality properties at raised temperatures. As a result of these qualities, metal matrix composites are getting looked at for a wide scope of applications. On account of their 
high thickness, they are not greatly requested. The most commonly used metals in the MMCs are steel, tungsten, boric and, molybdenum [22,23].

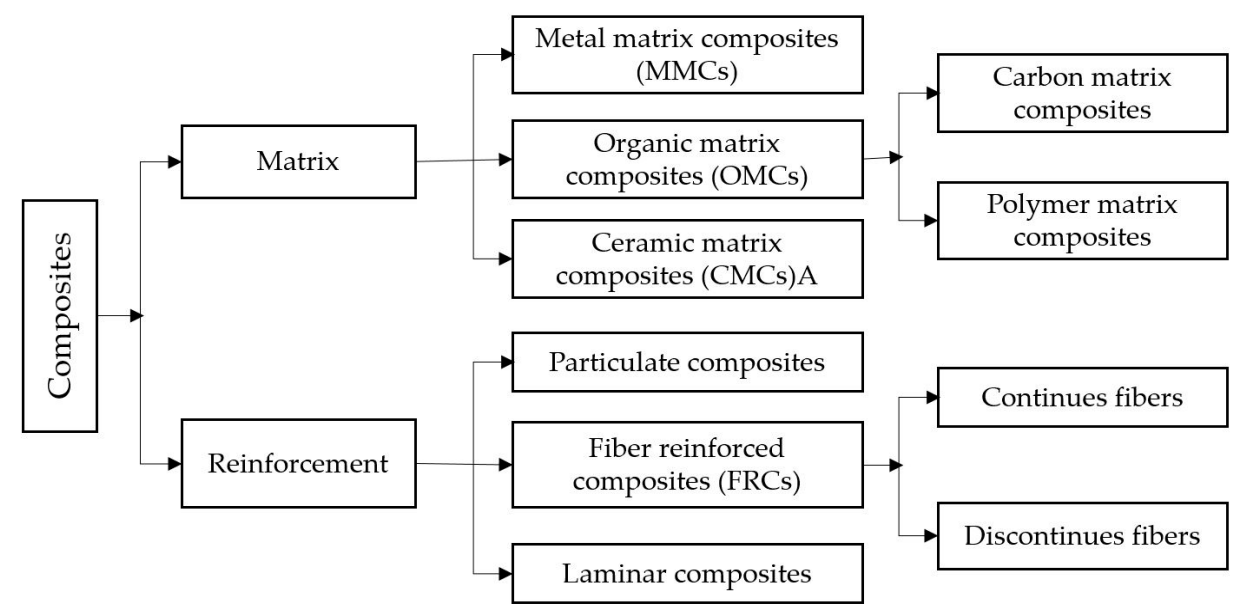

Figure 3. Classification of composites [22].

\subsection{Ceramic Matrix Composites (CMCs)}

Ceramic matrix composites (CMCs) and carbon-based composites are examples of inorganic (non-metallic) composite materials. The main aim of CMCs is to improve the toughness of the composite materials [24] and they are intended to overcome the problems of monolithic ceramics. The problem caused by the matrix materials is less than that of the failure of fiber materials, so it has a great impact on composite fabrication. To avoid the general drawbacks during the processing (early failure), there are several techniques implemented such as gas-phase and liquid-phase fabrication of CMCs.

\subsection{Organic Matrix Composites (OMCs)}

The organic matrix composites (OMCs) are broadly classified into polymer matrix composites and carbon-carbon matrix composites. Polymer composites are the most popular and commonly used matrix materials. The mechanical properties of polymeric composites are easily applicable to a wide range of structures because of their desirable mechanical properties, such as low mass, high stiffness and high-temperature resistance. When compared to the metal and ceramic composites, polymer composites have less strength and stiffness; to overcome this problem, composites are reinforced with other materials. The handling of polymer composites need not include high temperature and pressure. Likewise, the equipment required for the fabrication of composites is more straightforward. Therefore, polymer matrix composites quickly became famous and of interest for many researchers in terms of basic applications. Composites are utilized in light of the fact that the general properties of the composites are better than those of the specific segments.

Polymer composites are further classified as thermosets and thermoplastic composites. Thermoplastic materials are solids at room temperature; heating is required to soften or melt the material to place it into the mold and then it is cured to get the desired shape. These are recyclable. Thermosetting polymers are in both liquid and solid form and these are not recyclable. In thermoplastics, the atoms are bonded by covalent bonds whereas thermosetting polymers have cross-linked bonds, because these thermosetting materials are stronger and stiffer than thermoplastics. Thermoplastic materials include polyamides, polyoxymethylene (POM), polycarbonates (PC) and acrylics. Thermo setting materials include epoxies (EP), thermoset polyamides, amino plastics and polyester thermosets (TS) [24]. 


\subsection{Fiber Reinforced Polymer Composites (FRCs)}

Fiber Reinforced Polymer Composites (FRCs) are the most widely used composites and are composed of fiber and matrix. Fiber serves as a reinforcement and acts as a stiffness agent. The matrix material glues all fibers together and acts as a stress distributor among the fibers. Sometimes, the filler material is added to smooth the fabrication process. Depending upon the availability, reinforcements are classified into natural and synthetic fibers. Though there are many advantages to synthetic composites, there are some disadvantages. Synthetic fibers burn more quickly than natural fibers. Extra electrostatic charge is produced by rubbing them with natural fibers [23,25].

\section{Classification of Fibers}

\subsection{Natural Fibers}

Natural fibers are produced from animal (protein is the main component), plant (cellulose is the main component) and mineral based resources. Natural fibers have advanced physical and mechanical characteristics when compared to the other fibers. They are readily available in nature and also biodegradable [26,27]. Because of its lightweight, high strength, low cost and corrosion resistance properties it is drawing attention for use in industrial applications [28]. On the other side, natural fibers have few disadvantages, like high water absorption, high anisotropy, less homogeneity when compared to the synthetic fibers, development of stresses among the fibers in a composite [28]. The following Figure 4 shows the classification of natural fibers.

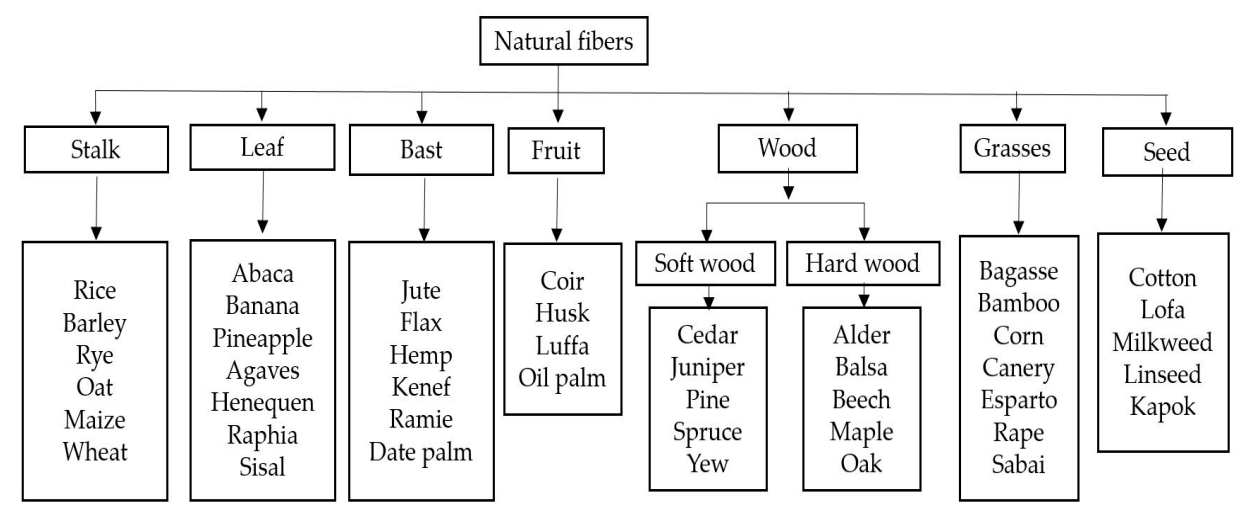

Figure 4. Classification of natural fibers [22-24].

The chemical composition plays a significant role in fiber materials and it depends on the fiber source. It varies from fiber to fiber and also within the family as shown in Table 1 . Their performance is mainly dependent on the aspect/ratio and cellulose crystallinity of the fibers. Previous studies stated that these fibers are biodegradable because of their chemical constitutes. For example, UV degradation because of lignin and hemicellulose is accountable for thermal and biodegradation and also water absorption. The physical and mechanical properties of the natural fibers are shown in Table 2 . Cellulose, hemicellulose and lignin are the main components in the natural fibers. Due to the nature of development conditions, the percentage of these components varies accordingly. To consider the behavior of these fibers, it is important to consider the structure of the components. Cellulose is one of the major building blocks of the natural fibers, it makes up around $50 \%$ of plants. The presence of cellulose in the plant fibers has an impact on moisture absorption. Hemicellulose is the second major component followed by cellulose and it is less remarkable as a filler material. Phenylpropane derivatives is comprised of lignin and it is a formless normal polymeric material that controls the transaction of fluid and also combines the hard cells in the plant. Lignin acts as a cementing material and it influences the structure, properties and morphology [29]. Some of the advantages and disadvantages of natural fibers are explained in Table 3. 
Table 1. Natural fibers chemical composition [22,24-26].

\begin{tabular}{|c|c|c|c|c|c|c|c|c|}
\hline Fiber Type & Cellulose (\%) & Hemi-Cellulose (\%) & Lignin (\%) & Pectin (\%) & Wax $(\%)$ & Ash (\%) & Moisture (\%) & Microfibrillar-Angle $\left(^{\circ}\right)$ \\
\hline Abaca & $56-63$ & $20-25$ & $7-9$ & - & 3 & - & - & $20-25$ \\
\hline Bamboo & $26-43$ & 30 & $1-31$ & - & 10 & - & 9.16 & - \\
\hline Banana & $63-83$ & - & 5 & - & 11 & - & 10.71 & $11-12$ \\
\hline Coir & $36-43$ & $41-45$ & $0.15-0.25$ & $3-4$ & - & - & 11.36 & $30-49$ \\
\hline Cotton & $83-91$ & 3 & - & 0.6 & $8-9$ & - & $7.85-8.5$ & - \\
\hline Flax & $64-72$ & $64-72$ & $2-2.2$ & $1.8-2.3$ & - & - & $8-12$ & $5-10$ \\
\hline Hemp & $70-74$ & 0.9 & $3.7-5.7$ & 0.8 & $1.2-6.2$ & 0.8 & $6.2-12$ & $2-6.2$ \\
\hline Jute & $61-72$ & $18-22$ & $12-13$ & 0.2 & 0.5 & $0.5-2$ & $12.5-13.7$ & 8 \\
\hline Kenaf & $45-57$ & $8-13$ & 22 & 0.6 & 0.8 & $2-5$ & $6.2-12$ & $2-6.2$ \\
\hline Nettle & 86 & 5.4 & 4.0 & 0.6 & 3.1 & - & - & - \\
\hline Rachis & 43 & - & 26 & - & - & - & - & $28-37$ \\
\hline Ramie & 69-91 & 5-15 & $0.4-0.7$ & 1.9 & - & - & - & $69-83$ \\
\hline Rice husk & $38-45$ & - & - & - & - & 20 & - & - \\
\hline Sisal & 78 & 10 & 8 & - & 2 & 1 & 11 & - \\
\hline Hardwood & $38-49$ & $17-23$ & $23-30$ & - & - & - & - & - \\
\hline Softwood & $40-45$ & $19-22$ & $26-34$ & - & - & - & - & - \\
\hline
\end{tabular}


Table 2. Natural fibers origin, physical and mechanical properties [22,26-28].

\begin{tabular}{|c|c|c|c|c|c|c|c|c|}
\hline Fiber Type & Origin & $\begin{array}{c}\text { Diameter } \\
(\mu \mathrm{m})\end{array}$ & $\begin{array}{c}\text { Density } \\
\mathrm{g} / \mathrm{cm}^{3}\end{array}$ & $\begin{array}{c}\text { Tensile Strength } \\
\text { (MPa) }\end{array}$ & $\begin{array}{l}\text { Young's Modulus } \\
\text { (GPa) }\end{array}$ & $\begin{array}{c}\text { Elongation } \\
(\%)\end{array}$ & $\begin{array}{c}\text { Specific Strength } \\
(\mathrm{S} / \varrho)\end{array}$ & $\begin{array}{c}\text { Specific Modulus } \\
(\mathrm{E} / \varrho)\end{array}$ \\
\hline Abaca & Leaf & - & 1.5 & $430-813$ & $31.1-33.6$ & $2.9-10$ & 267 & 8 \\
\hline Bagasse & Grass & - & 0.89 & 350 & 22 & 5.5 & - & - \\
\hline Banana & Leaf & $50-250$ & 1.35 & 529-914 & $27-32$ & $2.6-5.9$ & 444 & 13.2 \\
\hline Coir & Fruit & - & $1.15-1.25$ & $131-220$ & $4-6$ & $15-40$ & 146 & $3.3-5$ \\
\hline Cotton & Seed & - & 1.51 & 400 & 12 & $3-10$ & $179-373$ & $3.44-7.9$ \\
\hline Flax & Stem & - & 1.4 & $800-1500$ & $60-80$ & $1.2-1.6$ & 535-1000 & $18.4-53$ \\
\hline Jute & Stem & $40-350$ & $1.31-1.48$ & $393-800$ & $13-26.5$ & $1.16-1.8$ & 269-548 & $6.85-20.6$ \\
\hline Kenaf & Stem & $70-250$ & 1.4 & $284-930$ & $21-60$ & 1.6 & 641 & 36.55 \\
\hline Nettle & Bast & - & 1.51 & 650 & 38 & 1.7 & - & $87-115$ \\
\hline Pineapple & Leaf & - & 1.44 & $413-1627$ & $60-82$ & 14.5 & - & - \\
\hline Ramie & Stem & 50 & 1.5 & 500 & 44 & 2 & $147-675$ & 29.3-85 \\
\hline Sisal & Leaf & $50-300$ & $1.3-1.4$ & $390-450$ & $12-41$ & $2.3-2.5$ & $366-441$ & $6.5-15.2$ \\
\hline Softwood & Wood & - & 1500 & 1000 & 40 & - & 667 & 26.67 \\
\hline Hardwood & Wood & - & 1200 & 950 & 37.9 & - & - & - \\
\hline
\end{tabular}


Table 3. Merits and demerits of natural fibers.

\begin{tabular}{cc}
\hline Merits & Demerits \\
\hline Lightweight & Flammable \\
Recyclable & Dimensional instability \\
Improved specific mechanical properties & High moisture absorption \\
Eco-friendly & Anisotropic behavior \\
Do not generate any harmful gasses during processing & Limited processing temperature $\left(\sim 200-230^{\circ} \mathrm{C}\right)$ \\
Good thermal properties & Sensitive to UV \\
Good acoustic properties & Fugal attack and microbial \\
Low cost, availability & Low strength than synthetic fibers \\
\hline
\end{tabular}

\subsection{Synthetic Fibers}

There are various man-made or synthetic fibers that have been brought into recent research networks with respect to their remarkable properties. The mechanical properties of synthetic fibers are shown in Table 4. Among all synthetic fibers, glass and carbon fibers are the most used filler materials in the hybrid composites. These fibers are manufactured by using the polymerization concepts, which includes joining monomers to form a great chain. The merits and demerits of synthetic fibers explained in Table 5. Below Figure 5 shows the classification of synthetic fibers.

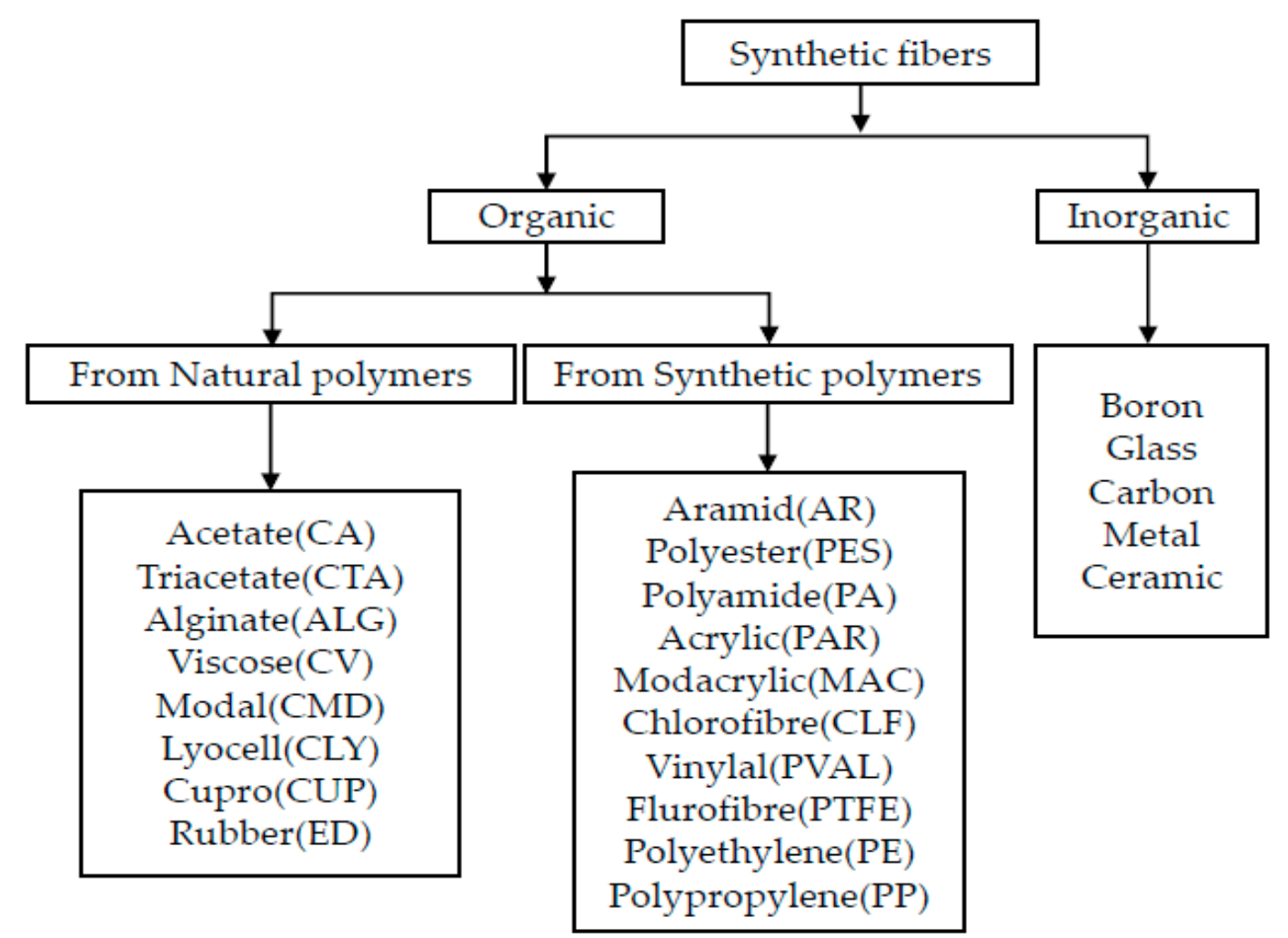

Figure 5. Classification of synthetic fibers [15]. 
Table 4. Mechanical properties of synthetic fibers [26-28].

\begin{tabular}{ccccc}
\hline Type of Fiber & $\begin{array}{c}\text { Density } \\
\left(\mathbf{g} / \mathbf{c m}^{\mathbf{3}} \mathbf{)}\right.\end{array}$ & $\begin{array}{c}\text { Tensile Strength } \\
\mathbf{( M P a )}\end{array}$ & $\begin{array}{c}\text { Young's Modulus } \\
\mathbf{( G P a )}\end{array}$ & $\begin{array}{c}\text { Elongation } \\
\mathbf{( \% )}\end{array}$ \\
\hline Aramid & 1.44 & 3000 & 124 & 2.5 \\
Carbon & 1.4 & 400 & $230-240$ & $1.4-1.8$ \\
E-Glass & 2.55 & $2000-3500$ & $63-67$ & 2.5 \\
S-Glass & 2.5 & 4570 & $70-73$ & $1.8-3.2$ \\
Silicon & 3.16 & - & $360-440$ & - \\
carbide & & & & \\
\hline
\end{tabular}

Table 5. Advantages and disadvantages of synthetic fibers.

\begin{tabular}{cc}
\hline Advantages & Disadvantages \\
\hline Long lasting & Flammable \\
Readily pick-up to various dyes & Prone to heat damage \\
Stretchable & Melt easily \\
Waterproofing & Not eco-friendly \\
Non biodegradability & Cause for microplastic pollution \\
Moisture resistance & Not suitable for hot washing \\
Strain and wear resistance & Poor insulation capacity \\
\hline
\end{tabular}

\section{Chemical Treatment of Natural Fibers}

Natural fibers are not defect-free materials even though they have great qualities when compared to the other advanced fibers. They have strong polar bonds, which may affect the bonding capability in the polymer matrix [30]. To avoid this, some sort of chemical treatment is required to improve it. Chemical treatment is one that gives additional strength to the composite material to develop a relationship between fiber and matrix material during the curing process. It also improves the surface quality and decreases the amount of water absorbed (Moisture content) by the composite material [31]. Some of these treatment techniques are listed down in Table 6. 
Table 6. Chemical treatment processes and its importance on hybrid fiber composites.

\begin{tabular}{|c|c|c|c|}
\hline Chemical Treatment & Fibers & Advantages & Reference \\
\hline Alkaline treatment & $\begin{array}{l}\text { Flax } \\
\text { Jute } \\
\text { Sisal }\end{array}$ & $\begin{array}{l}\text { Improves the surface roughness } \\
\text { Better mechanical interlocking, and } \\
\text { cellulose content. }\end{array}$ & [32-34] \\
\hline Silane treatment & Glass & $\begin{array}{l}\text { Prevent swelling of composite } \\
\text { Improve thermal stability. }\end{array}$ & {$[35,36]$} \\
\hline Acetylation treatment & Sisal & Improve the bio-resistance of a composite and fiber-matrix interactions. & {$[37,38]$} \\
\hline Benzoylation treatment & $\begin{array}{l}\text { Flax } \\
\text { Sisal }\end{array}$ & Reduces the moisture absorption, improve its thermal stability and strength. & [39-41] \\
\hline Acrylonitrile grafting and Acrylation & $\begin{array}{l}\text { Oil palm } \\
\text { Glass }\end{array}$ & It improves the tensile strength and young's modulus. & [42] \\
\hline Malleated coupling gents & $\begin{array}{c}\text { Cellulose fibers } \\
\text { Banana } \\
\text { Hemp }\end{array}$ & Growth in flexural strength, hardness, impact strength and flexural modulus. & {$[43,44]$} \\
\hline Permanganate treatment & Cellulose fibers & It improves the hydrophilic tendency of the composite. & [45] \\
\hline Peroxide treatment & Oil palm & Improves tensile properties. & [45] \\
\hline Isocyanate treatment & Leaf fibers & Enhance better mechanical properties. & {$[46,47]$} \\
\hline
\end{tabular}




\section{Selection of Matrix Materials for Fabrication}

A matrix material is one which plays an adverse role in the composite material. The shape, durability and surface properties depend on matrix (resin) material. Based on processing techniques, resin materials are classified into two types, such as thermosets and thermoplastics [48]. A matrix is used as a load distributer among the reinforcement material when external pressure is applied. Thermoplastics are widely used resin material over thermosets because of its ready pick-up shape to the required mold (moldability). Thermosets are not recyclable because it does not come back to its original state when the resin is converted from liquid state to solid state after the curing process. Only a heating process is required for the thermoplastics to form a new shape.

\subsection{Thermoplastics}

Researchers are showing interest in using thermoplastics as matrix materials because of their integral properties, such as low cost, moldability, less weight and recyclability. The main advantages and disadvantages of these thermoplastic polymer materials are discussed below in Table 7 . The viscosity range is more than 500 times that of uncured thermosets during the melting process. Recent results proved that the addition of chemical treatment to the natural fibers may lead to improving the bonding properties between matrix and reinforcement [49], chemical treatments such as; alkaline, silane, acetylation, benzoylation treatments and many others. Due to the addition of chemical and biological treatments, the overall properties of composites are improved [50]. Among all synthetic polymers, thermoplastics are the most commonly used commercial purpose materials. The most widely used thermoplastics are polyvinyl chloride (PVC), polystyrene (PS), polypropylene (PP), polyethylene and natural rubber. The mechanical properties of thermoplastic resins are explained in Table 8.

Table 7. Thermoplastic resins advantages and disadvantages.

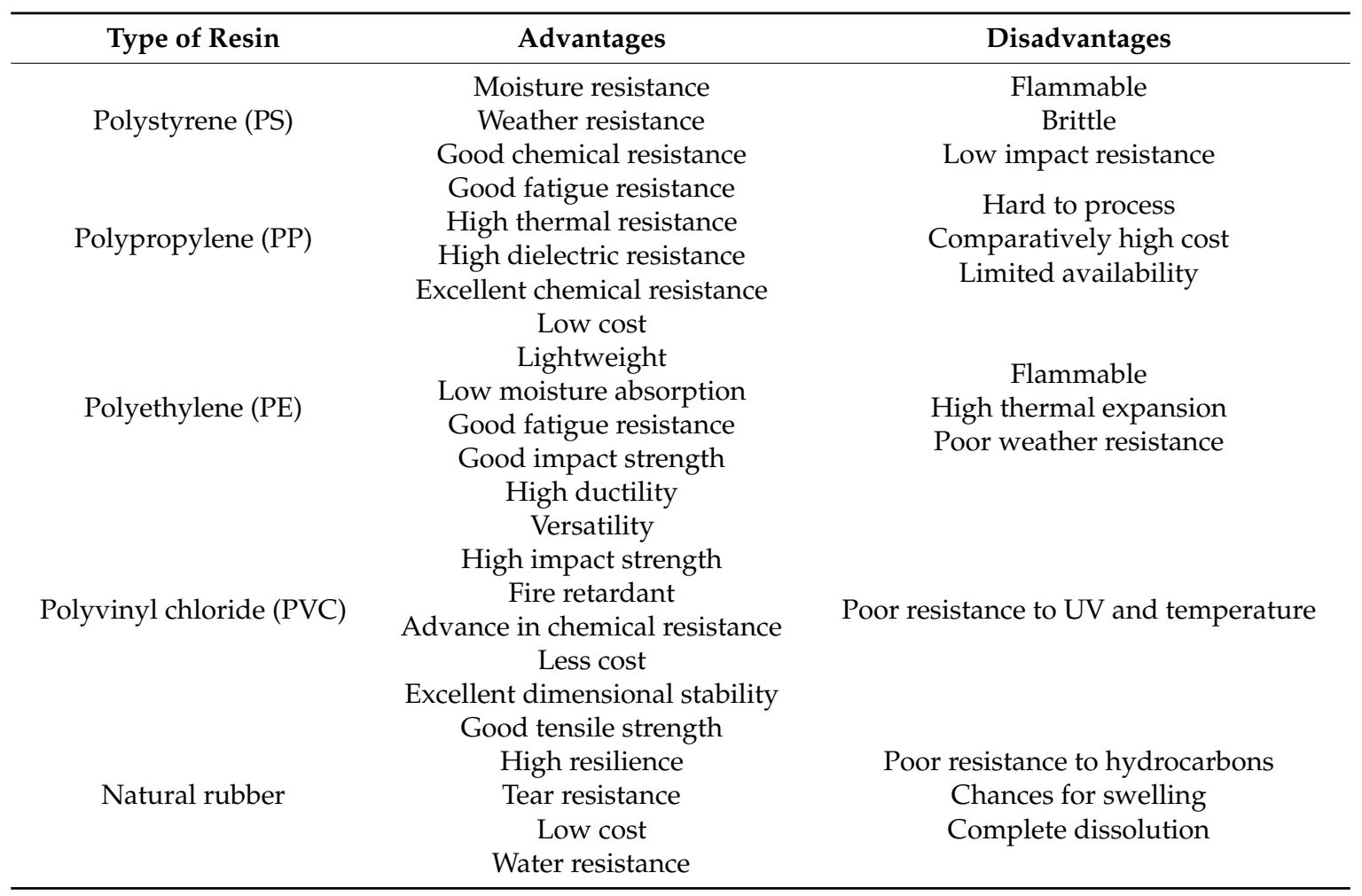

Kasama et al. investigated the mechanical and thermal properties of sisal and glass fibers as reinforcement and polypropylene as a matrix material [51], the authors reported that the addition of polypropylene to the hybrid composites causes improvement in thermal stability, moisture resistance 
and also interfacial adhesion between reinforcement and matrix improved. Schmidt et al. reported the mechanical properties of the hybrid composites by using the RTM (resin transfer molding) technique [52]. They analyzed the woven and non-woven composites by in-plane permeability of the hybrid composites and draw a contrast between both of them for comparison purposes and reported that improved mechanical properties and flow media of sisal fibers and glass mats by adding pp to the hybrid composite. Nayak et al. summarized the dynamic mechanical and rheological properties of bamboo glass fiber hybrid composite PP as a resin material by using an injection molding technique [53]. Interestingly, the researcher found that the addition of Maleic anhydride grafted polypropylene (MAPP) in place of normal PP has given advanced results. Vega-Hernandez et al. developed the composites grounded on blue agave bagasse by using polystyrene as a resin matrix [54]. They have invested in the mechanical performance of the hybrid composites by in situ reversible addition-fragmentation chain transfer (RAFT).

Haneefa et al. worked on the tensile and flexural properties of banana and glass fiber reinforced PS composites [55]. It was discovered that the rigidity and modulus of the composite increases by increments in the volume part of the glass fiber. This is expected due to the more noteworthy similarity of glass fiber than banana fiber to polystyrene. In any case, the stretching at break diminishes in increments in the volume portion of glass filaments-this is because of the lower prolongation at the break estimation of glass fiber. Experiments proved that chemical modifications of composites exhibit $30 \%$ greater mechanical properties than normal composites. Hao $\mathrm{X}$ et al. examined the effects of fiber geometry and alignment on the anisotropy of the flexural and thermal expansion of natural fiber polyethylene hybrid composites [56]. Samples were fabricated by using the extrusion process and, to find out the fiber orientation effectiveness, composites are cut by various off-set angles for comparison purposes and the results showed that at zero angle, composites showed the best mechanical properties whereas at 90 degrees some deviation was observed. Robledo-Ortiz et al. developed green polyethylene natural fiber bio composites by using a rotational molding technique [57]. In this work, composites were prepared by using the rotomolded (rotational molding) technique to develop the bio composites. Natural fibers were combined in a low-density green polyethylene medium and after fabrication, samples were taken for testing mechanical properties. Maleate polyethylene (MAPE) was utilized for surface treatment with the purpose of increasing its adhesion properties. Results indicated that its less elastic nature was because of its poor bonding capacity between reinforcement and matrix. Paran et al. examine the dynamic properties of the green thermoplastic elastomer vulcanizate (GTEV) nanocomposites based on poly vinyl chloride (PVC) and rice straw as reinforcements [58]. The surface morphological studies exposed that the GTEV nanocomposite showed a great surface roughness fracture and specified the presence of some relations between the matrix material and natural fibers [59]. The effect of loading on fibers was foreseen through using the parallel and serious equations [60]. Boussehel et al. worked on the impact of chemical treatment on polyvinyl chloride natural fiber hybrid composites [61]. In this research, the authors drew a contrast between the PVC with and without the chemical treatment of natural hybrid composites and the results showed a slight variation in the mechanical properties [62]. But there is a change of structure for natural fibers after chemical treatment due to the formation of hydroxyl bonds [63]. Haseena et al. carried out research on the interfacial adhesion of natural hybrid fiber natural rubber composites by using the equilibrium technique [64]. The swelling coefficient was found to diminish with an expansion in fiber stacking and penetrant size. The holding operator added blends demonstrated more noteworthy limitation to growth because of the more grounded interfacial grip and the resultant higher cross-linked density [65]. The recent research on various fabrication techniques of thermoplastic resins is discussed in Table 9. 
Table 8. Mechanical properties of thermoplastic resins.

\begin{tabular}{|c|c|c|c|c|c|}
\hline Polymer & $\begin{array}{l}\text { Density } \\
\left(\mathrm{g} / \mathrm{cm}^{3}\right)\end{array}$ & $\begin{array}{c}\text { Tensile Strength } \\
\text { (MPa) }\end{array}$ & $\begin{array}{l}\text { Young's Modulus } \\
\text { (GPa) }\end{array}$ & $\begin{array}{c}\text { Elongation } \\
(\%)\end{array}$ & $\begin{array}{c}\text { Glass Transition } \\
\text { Temp. }\left({ }^{\circ} \mathrm{C}\right)\end{array}$ \\
\hline Polyethylene (PE) & 0.9 & 18.0 & 0.5 & 350.0 & -78.0 \\
\hline High-density polyethylene (HDPE) & $0.9-1.0$ & $32.0-38.2$ & 1.3 & 150.0 & -110.0 \\
\hline Polyethylene terephthalate (PET) & $1.5-1.6$ & $55.0-159.0$ & $2.3-9.0$ & 300.0 & 67.0 \\
\hline Polystyrene (PS) & 1.04 & 34.0 & 3.0 & 1.6 & 100.0 \\
\hline High-impact polystyrene (HIPS) & 1.0 & 42.0 & 2.1 & 2.5 & $88.0-92.0$ \\
\hline Poly methyl methacrylate (PMMA) & $1.1-1.2$ & 72.4 & 3.0 & 2.5 & 125.0 \\
\hline Polyvinyl chloride (PVC) & $1.3-1.5$ & $52.0-90.0$ & $3.0-4.0$ & $50.0-80.0$ & 82.0 \\
\hline Nylon 6 (PA 6) & 1.1 & 81.4 & 2.8 & 60.0 & 47.0 \\
\hline Nylon 6,6 (PA 6,6) & 1.1 & 82.7 & 2.8 & 60.0 & 70.0 \\
\hline
\end{tabular}

Table 9. Recent research on thermoplastic hybrid composites and fabrication techniques.

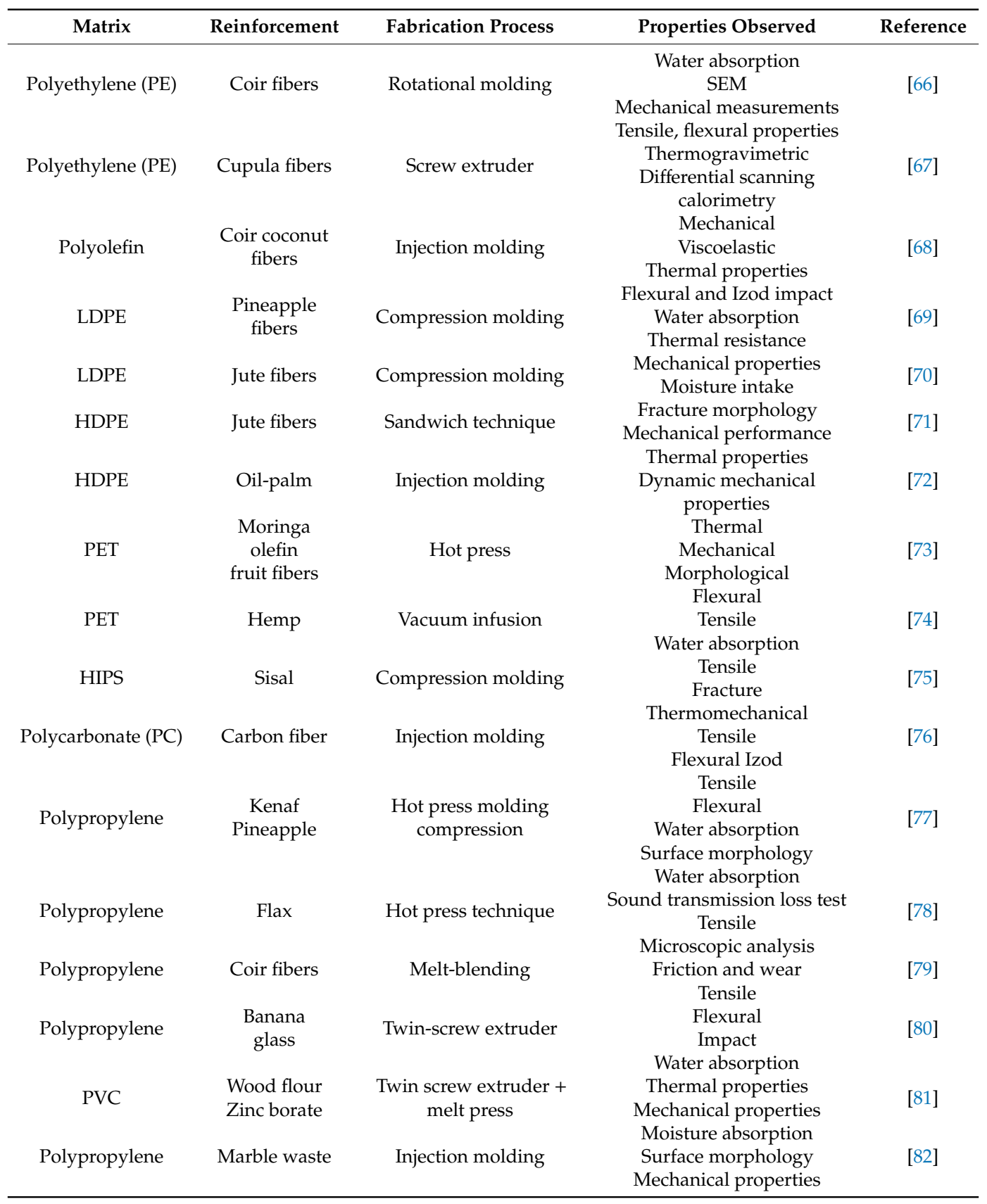




\subsection{Thermosets}

Thermosets are well known for their exclusive uniqueness of making 3-dimensional bonds after curing. Thermoset resin far differs from thermoplastics and these have improved mechanical properties, thermal stability, resistance to the creep and biodegradability [83]. The merits and demerits of some of the thermoset resins are explained in Table 10. Unlike thermoplastics, thermosets are not reusable materials [84]. Epoxy resin, vinyl ester, polyester, phenolic, urea-formaldehyde and many others are some of the examples for thermoset polymers. Among all the resins, epoxy and vinyl ester are widely used resins because of their availability, flexibility and low cost [85]. The primary worry for thermosets is the long length related to handling. Moreover, with the low recyclability of these composites, they require new procedures of structuring maintainable reusing components. For instance, they can be crushed and utilized again as filler materials. The primary target has been the adjustment of the durability of the thermosets and augmenting the handling temperatures. Because of the enhancing mechanical properties as shown in Table 11, thermoset based composites have a huge market for commercial purposes such as the aerospace industry, sports equipment, lightweight objectives, construction field, automobile, biomedical and many other real-life applications. Amongst all these, epoxy resin along with hardener is mostly used in hybrid composite fabrication. There are several processing techniques (Table 12) available in the present time, including the hand lay-up technique, the combination of hand lay-up with compression molding, pultruded, hot press molding, twin-screw extruder and the vacuum assisted resin transfer molding technique (VARTM). The hand lay-up process is mostly used because of cost-effectiveness and easy procedure with improved results. Although there are some drawbacks like curing process, nonuniformity of resin material, vacuum voids in the composite and these are considerably lower compared to the other techniques.

Table 10. Merits and demerits of thermoset resins.

\begin{tabular}{|c|c|c|}
\hline Type of Resin & Advantages & Disadvantages \\
\hline Epoxy resin & $\begin{array}{c}\text { High water resistance } \\
\text { High thermal and mechanical } \\
\text { properties } \\
\text { Low curing time } \\
\text { Durability }\end{array}$ & $\begin{array}{l}\text { Difficult to process } \\
\text { Corrosive amine hardener } \\
\text { More expensive than vinyl ester }\end{array}$ \\
\hline Vinyl ester & $\begin{array}{c}\text { High chemical resistance } \\
\text { High mechanical properties than } \\
\text { polyester }\end{array}$ & $\begin{array}{c}\text { High curing shrinkage } \\
\text { High styrene content } \\
\text { Needs post curing } \\
\text { More expensive } \\
\text { Limited access }\end{array}$ \\
\hline Polyester & $\begin{array}{l}\text { Lowest cost } \\
\text { Easy to use }\end{array}$ & $\begin{array}{c}\text { moderate mechanical properties } \\
\text { Huge curing shrinkage } \\
\text { High gas emissions }\end{array}$ \\
\hline Phenolic & High fire retardance & Hard to develop \\
\hline
\end{tabular}

Table 11. Mechanical properties of thermoset resins.

\begin{tabular}{cccccc}
\hline Polymer & $\begin{array}{c}\text { Density } \\
\left(\mathbf{g} / \mathbf{c m}^{\mathbf{3}}\right)\end{array}$ & $\begin{array}{c}\text { Tensile Strength } \\
\mathbf{( M P a )}\end{array}$ & $\begin{array}{c}\text { Young's Modulus } \\
(\mathbf{G P a})\end{array}$ & $\begin{array}{c}\text { Elongation } \\
(\%)\end{array}$ & $\begin{array}{c}\text { Glass Transition } \\
\text { Temp. }\left({ }^{\circ} \mathbf{C}\right)\end{array}$ \\
\hline Epoxy resin (EP) & $1.2-1.3$ & 600.0 & 80.0 & 1.3 & $70.0-167$ \\
Urea formaldehyde (UF) & $1.5-1.6$ & 65.0 & 9.0 & 0.8 & 130.0 \\
Melamine formaldehyde (MF) & $1.5-1.6$ & 65.0 & 12.0 & 0.6 & 150.0 \\
Phenol formaldehyde (PF) & 1.2 & 45.0 & 6.5 & 1.2 & 170.0 \\
Unsaturated polyester (UPE) & 1.1 & 60.0 & 3.4 & 2.0 & $110.0-188.0$ \\
Rigid thermoset polyurethane (RPU) & 1.2 & 60.0 & 2.2 & 90.0 & $-150.0-0.0$ \\
\hline
\end{tabular}

Yorseng et al. developed the bio-based natural fibers hybrid bio epoxy composites for the application of semi-structured components and their mechanical behavior under various circumstances was observed [86]. Surface morphology was conducted by using contact angle measurement properties 
to find the wettability of the composites. The results showed that a decrease in mechanical properties because of the bio epoxy degradation by accelerated weathering conditions and the ductile nature of the composite are increased and it causes breakdown [87-89]. Thermal studies stated that bio-epoxy based natural fiber composites withstand up to $295^{\circ} \mathrm{C}$ temperature, which means these composites are valid for high-temperature applications. Alves et al. examined the dynamic mechanical properties of hybridized jute and biaxial glass fiber reinforcement and epoxy as matrix material composites [90]. The vacuum infusion technique was used for the best impregnation level for both fibers during the fabrication process. This paper offered the woven and non-woven fabrics reinforced epoxy resin composites and the effect of fiber arrangement on mechanical properties. Asim et al. investigated the dynamic and mechanical characteristics of Kenaf and pineapple fibers reinforced phenolic hybrid composites [91]. Test samples were prepared by using the hydraulic hot press and fibers were ground up to 0.1 to $0.8 \mathrm{~mm}$ and compressed for $8 \mathrm{~min}$ to get the desired shape and then used for testing purposes. From the outcomes, it is seen that kenaf composites showed advanced mechanical properties whereas pineapple showed the least stability under phenolic resin but the difference is not very comparative [92]. The wear resistance of natural corn stalk fiber reinforced phenolic resin composites were prepared by using the wet granulation technique [93]. The effect of phenolic resin on the brake friction materials was observed by varying the percentage of resin matrix in the composite weight. Results showed that the wet granulation method improves the surface morphology of the friction materials and also stated that tribological behavior also increased.

Singha et al. worked on the synthesis and characterization of pine needles reinforced resorcinol-formaldehyde (RF) biocomposites [94]. Composite sheets by varying the fiber loadings were fabricated by using the compression molding technique and allowed for mechanical properties testing. Results showed that pine needle composites showed more improved mechanical properties than neat RF resin composites. Composite strength increased along with fiber loadings so it has the potential as a replacement for synthetic fibers. Singha et al. investigated the mechanical, thermal and morphological properties of grewia optiva fiber reinforced resorcinol-formaldehyde polymer composites [95]. Composites were fabricated by using the compression molding technique. Fibers were taken in the form of particles for the fabrication and test specimens allowed for material properties testing and composites were prepared by varying the fiber loadings (by weight). Results showed that an increase in mechanical properties up to 30\% fiber loadings and then a slight decrease in it due to weak bonding between matrix and reinforcement material in the composite. Thakur et al. studied the mechanical properties of hibiscus sabdariffa fiber reinforced urea-formaldehyde (UF) green composites [96]. Results suggested an improvement in mechanical properties and there is a huge difference between the fiber composites and neat UF resin composites. Fiber composites are much stronger than pure resin composites. Singha et al. worked on the fabrication and characterization of saccharum cilliare fiber-reinforced resorcinol formaldehyde green composites [97]. Samples were fabricated on a compression molding machine. These test specimens were allowed for mechanical properties testing. Results suggested that saccharum cilliare fibers composite were higher than the matrix composites and these fibers have the potential to be used in composite fabrication. 
Table 12. Recent research on thermoplastic hybrid composites and fabrication techniques.

\begin{tabular}{|c|c|c|c|c|}
\hline Matrix & Reinforcement & Fabrication Process & Properties Observed & Reference \\
\hline Epoxy & $\begin{array}{l}\text { Hemp fibers } \\
\text { Flax fibers }\end{array}$ & Hand layup & $\begin{array}{c}\text { Mechanical } \\
\text { Moisture analysis } \\
\text { Contact angle measurement }\end{array}$ & [98] \\
\hline Epoxy & $\begin{array}{l}\text { Jute fibers } \\
\text { glass fibers }\end{array}$ & Vacuum infusion & $\begin{array}{l}\text { Compressive strength } \\
\text { Shear strength }\end{array}$ & [90] \\
\hline Epoxy & $\begin{array}{l}\text { Crab shell } \\
\text { Sisal fibers }\end{array}$ & Compression molding & $\begin{array}{c}\text { Mechanical } \\
\text { Chemical } \\
\text { Morphological }\end{array}$ & [99] \\
\hline Epoxy & $\begin{array}{l}\text { Woven cotton } \\
\text { Bamboo }\end{array}$ & Compression molding & $\begin{array}{l}\text { Flexural } \\
\text { Tensile } \\
\text { Impact }\end{array}$ & [100] \\
\hline Epoxy & $\begin{array}{l}\text { Basalt fiber } \\
\text { UHMWPE }\end{array}$ & Compression molding & $\begin{array}{l}\text { Impact } \\
\text { Tensile } \\
\text { Compression }\end{array}$ & [101] \\
\hline Epoxy & $\begin{array}{c}\text { Glass } \\
\text { Basalt woven }\end{array}$ & $\begin{array}{l}\text { Resin transfer molding } \\
\text { technique }\end{array}$ & $\begin{array}{l}\text { Mechanical properties } \\
\text { Impact behavior }\end{array}$ & [102] \\
\hline Epoxy & $\begin{array}{l}\text { Pineapple } \\
\text { Basalt }\end{array}$ & Compression molding & $\begin{array}{c}\text { Mechanical properties } \\
\text { Tensile } \\
\text { Flexural } \\
\text { Damping }\end{array}$ & [103] \\
\hline Epoxy & $\begin{array}{l}\text { Sisal } \\
\text { Banana } \\
\text { Coir }\end{array}$ & Compression molding & $\begin{array}{c}\text { Hardness } \\
\text { Tensile } \\
\text { Flexural } \\
\text { Water absorption }\end{array}$ & [104] \\
\hline Epoxy & $\begin{array}{l}\text { Kevlar } \\
\text { Cocos } \\
\text { nucifera }\end{array}$ & $\begin{array}{l}\text { Compression molding } \\
+ \text { hand layup }\end{array}$ & $\begin{array}{l}\text { Thermal } \\
\text { Mechanical }\end{array}$ & [105] \\
\hline Epoxy & $\begin{array}{l}\text { Carbon } \\
\text { Flax }\end{array}$ & Hand layup & Impact strength & [106] \\
\hline Epoxy & $\begin{array}{l}\text { Jute } \\
\text { Basalt }\end{array}$ & Hand layup & $\begin{array}{l}\text { Mechanical properties } \\
\text { Water absorption }\end{array}$ & [107] \\
\hline Epoxy & $\begin{array}{l}\text { Bamboo } \\
\text { Kenaf }\end{array}$ & Hand layup & Thermal properties & [108] \\
\hline Epoxy & $\begin{array}{l}\text { Banana } \\
\text { Flax }\end{array}$ & Hand layup & $\begin{array}{l}\text { Tensile strength } \\
\text { Flexural strength } \\
\text { Thermal properties }\end{array}$ & [109] \\
\hline Epoxy & $\begin{array}{c}\text { Neem } \\
\text { Banyan leaf }\end{array}$ & Hand layup & $\begin{array}{l}\text { Thermal stability } \\
\text { Thermogravimetry }\end{array}$ & [110] \\
\hline Epoxy & $\begin{array}{l}\text { Coir } \\
\text { Kevlar }\end{array}$ & Hand layup & Mechanical properties & [111] \\
\hline $\begin{array}{l}\text { Vinyl } \\
\text { ester }\end{array}$ & Glass & $\begin{array}{c}\text { The Electroless plating } \\
\text { method }\end{array}$ & $\begin{array}{l}\text { Thermal wear analysis } \\
\text { Mechanical properties }\end{array}$ & [112] \\
\hline $\begin{array}{l}\text { Vinyl } \\
\text { ester }\end{array}$ & $\begin{array}{l}\text { Flax } \\
\text { Basalt }\end{array}$ & $\begin{array}{l}\text { Resin infusion and } \\
\text { hand layup }\end{array}$ & $\begin{array}{l}\text { Impact strength } \\
\text { Mechanical characteristics }\end{array}$ & [113] \\
\hline $\begin{array}{l}\text { Vinyl } \\
\text { ester }\end{array}$ & $\begin{array}{l}\text { Flax } \\
\text { Basalt }\end{array}$ & $\begin{array}{c}\text { Vacuum assisted resin } \\
\text { infusion }\end{array}$ & $\begin{array}{l}\text { Interlaminar strength } \\
\text { Fracture toughness }\end{array}$ & [114] \\
\hline $\begin{array}{l}\text { Vinyl } \\
\text { ester }\end{array}$ & $\begin{array}{c}\text { Flax } \\
\text { Basalt }\end{array}$ & Vacuum infusion & $\begin{array}{l}\text { Fracture toughness } \\
\text { Water absorption }\end{array}$ & [115] \\
\hline Epoxy & $\begin{array}{l}\text { Napier } \\
\text { Glass }\end{array}$ & Cold Pressing & Tensile properties & [116] \\
\hline $\begin{array}{l}\text { Epoxy } \\
\text { resin }\end{array}$ & $\begin{array}{l}\text { Sisal } \\
\text { Coir }\end{array}$ & Cold Pressing & $\begin{array}{l}\text { Moisture absorption } \\
\text { Fire retardation }\end{array}$ & [117] \\
\hline $\begin{array}{l}\text { Epoxy } \\
\text { resin }\end{array}$ & $\begin{array}{l}\text { Long kenaf } \\
\text { Woven glass }\end{array}$ & Cold Pressing & $\begin{array}{l}\text { Fracture toughness } \\
\text { Water absorption }\end{array}$ & [118] \\
\hline PLA & $\begin{array}{c}\text { Sisal } \\
\text { Hemp fibers }\end{array}$ & $\begin{array}{l}\text { Injection molding+ } \\
\text { Extrusion }\end{array}$ & $\begin{array}{l}\text { Mechanical properties } \\
\text { Thermal stability }\end{array}$ & [119] \\
\hline
\end{tabular}




\subsection{Bio-Based Resins}

Bio-based polymeric resins are produced from renewable sources. These are classified into three types based on their physical properties. The first one is fully bio-based and biodegradable resins those are polyhydroxyalkanoates (PHA) and starch, the second one is partial bio-based resins those are polylactic acid (PLA) and cellulose and the last one is partial non-biodegradable resins those are polyethylene terephthalate (PET) and polyethylene. Most of these bio-based resins are originated from plants and plants-based sugars. The merits and demerits of bio-based resins are discussed in Table 13.

Table 13. Merits and demerits of bio-based resins.

\begin{tabular}{ccc}
\hline Resin & Merits & Demerits \\
\hline \multirow{3}{*}{ Cellulose } & Inexpensive & \\
& Easily available & \\
& Ease to adjust & Relative low decomposition \\
& High moisture absorption \\
& Intermediate heat resistance & \\
& Eco-friendly & Low stability \\
Polyhydroxy alkenoates (PHA) & Biodegradable & Fragile \\
& High molecular weight & Low decomposition \\
& Nontoxic nature & costly \\
Polylactic acid & High strength & Brittle \\
& High modulus & Pow cost \\
& Low cost & Low thermal degradation \\
Starch & Biodegradable & Hard to process \\
& & Water sensitive \\
& & Brittle \\
\hline
\end{tabular}

\section{Integration of Nanoparticles in Natural Fiber Hybrid Composites}

Hybrid composites are not defected free materials because of the fabrication errors, voids in the composite, weak bonding between matrix and reinforcement, environmental conditions, errors during the development and curing period, scratches on the fiber materials, impurities, unbalanced proportion of matrix and reinforcement affect the total performance of the composite materials [120]. Limiting the reasons for corrupting components can assist with keeping the presentation of composite materials. The addition of new constituents and material advancement quality control techniques is necessary to progress the performance of the hybrid composites. One of the best ways to overcome these problems is the integration of nanoparticles or nano constituents. Recent reports state that the addition of nanofillers in the composite materials showed greater improvement in mechanical properties such as tensile strength, flexural strength, creep strength, tensile strain, shear modulus, impact strength and also thermal properties than individual polymer-based hybrid composites [121].

Nowadays researchers are using three types of nanofillers to improve the performance of the composite material. They are classified into three main groups such as nanotubes, nanoparticles and nanolayers. Nanofillers are used based on the particle sizes-one dimensional, two dimensional and three dimensional. Nanomaterials are larger than macro-level particles, individual atoms and also have a huge surface area per unit volume. Most of them are produced from metals, carbon, polymers and metal oxides. Nano clay, carbon nanotubes, carbon black and graphene are the best example of metal-based nanofillers and also widely used nanomaterials.

Pappu et al. worked on unused materials, like fly ash and sisal fibers, to prepare the micro and nanocomposites for multifunctional applications [122]. The hand layup technique along with compression molding used for the preparation of composites, fly ash and sisal fibers were used as reinforcement and epoxy used as a matrix material. They prepared a total of two composites fabricated for comparison purposes. Results indicated that the presence of natural fiber and nanofiller boost the 
performance of the composite, particularly the cellulose content in the sisal fiber and silica along with alumina in fly ash leads to the potential growth of mechanical properties. Majeed et al. reported on food packaging materials from natural fiber hybrid composites, which have nanofiller as nano clay [72] and developed a new method to enhance the bonding between matrix and reinforcement. The addition of nano clay to the hybrid, composite showed good progress in mechanical and thermal properties. But these are not suitable for all types of packaging applications because of higher biodegradability and moisture absorption properties than that of synthetic fibers. Essabir et al. investigated the mechanical and thermal properties of clay and palm fiber hybrid composites [123]. They reported that the hybridization of oil-palm incorporated with clay particles showed improved tensile and young's modulus properties. Similar tests were reported by Arrakhiz et al. In this work, they reported the effect of mechanical and thermal properties of pine fiber reinforced with clay particles hybrid composites [124]; the results were similar to those of the previous research. The addition of clay particles leads to the elimination the voids in the composite surface and adversely affect the surface properties and overall performance of the composite.

Nanoclay particles are one of the most commonly used filler materials due to its availability and inexpensiveness. It comes under the silicate group nanomaterials. Nanoclay particles in the composite material can increase the mechanical, physical and chemical properties. The size and shape of the particles also plays an important role in the composite material for the strength and bonding between reinforcement and matrix material. Toyota automobile industries first started using the nanoclay particles in the polymer composite fabrication [125]; in this research work, the author has shown the importance of clay particles as a filler material to create the interfacial bond between the matrix and reinforcement and an improvement in the physical and fracture toughness of the composite material. Due to advancements in the material properties by using the nanoclay particles, the materials have been used in several functional and structural applications. The microstructure of the nanoparticles present in the material plays a key role in the improvement of mechanical properties.

Generally, nanoclays are available in several forms such as nanoclay platelets, calcined nanoclay and natural montmorillonite (CB). Assaedi et al. investigated the effect of nanoclay platelets (also called cloisite 30B) on the thermal and mechanical properties of fly ash geopolymer [126]. In this study, the platelets are added by varying the weight percentages such as $1 \%, 2 \%$ and $3 \%$ loadings. Results showed that adding the nanoclay platelets to the geopolymer shows a slight increase in mechanical properties. Flexural strength and flexural modulus were increased significantly with an increase in nanoclay loading up to $2 \%$ weight loading. After $2 \%$ weight, the properties of the materials slightly decreased due to porosity and poor dispersion. It is evident that continuous adding of the filler materials to the geopolymers does not increases its mechanical properties. On the other hand, Assaedi also stated the conditions for the temperature variant; he studied this by using the thermo-gravimetric analysis in terms of weight. It was observed that most of the weight loss occurred at $3 \%$ nanoclay loading due to extra friction.

Hakamy et al. studied the effect of calcined nanoclay $(\mathrm{CNC})$ on mechanical and microstructural properties of hemp fiber reinforced Portland cement nanocomposites [127]. Calcined nanoclay was prepared by using the heat treatment process of nanoclay particles at 800,850 and $900{ }^{\circ} \mathrm{C}$ temperature for $2 \mathrm{~h}$. It was found that nanoclay converted into a calcined state at $900{ }^{\circ} \mathrm{C}$. Experimental results suggest that the mechanical properties, such as flexural strength and fracture toughness, were improved by adding the $\mathrm{CNC}$ to the composite material. Calcined nanoclay particles were added by varying its weight percentages such as $1 \%, 2 \%$ and $3 \%$. The optimum hemp fabric content was found as $6.9 \%$ and $\mathrm{CNC}$ was found as $1 \%$.

Eesaee et al. worked on the effect of nanoclay particles in the reinforced glass/woven fiber composites with phenolic resins [128] and mainly dealt with the natural montmorillonite (CN) and artificial montmorillonite (CB). The filler material improved the composite performance because of the proper dispersion of nanoclay particles on the composite surface, which lead to better interfacial bonding with the matrix and reinforcement. It was exposed that the amalgamation of $2.5 \mathrm{wt} . \%$ of the 
filler material boosts the elastic modulus up to $38 \%$ for $\mathrm{CN}$ and $43 \%$ for $\mathrm{CB}$. On the other side, aging with water molecules and hydroxyl groups of the phenolic matrix leads to a decrease in the strength of the composite.

Avil et al. observed the effect of porosity and failure strength in the presence of nanoclay in glass fiber reinforced epoxy composites [129]. The results showed that the additional filler material caused the reduction of porosity by $73.2 \%$ at $10 \mathrm{wt} . \%$. Binu et al. studied the effect of nanoclay, cloisite $15 \mathrm{~A}$, on the mechanical performance and thermal properties of polyester-based glass fiber composites [130]. The results showed a maximum mechanical performance observed at $1 \%$ loading of the filler materials to the composite. According to this study, the glass transmission temperature failed in between 95 and $110^{\circ} \mathrm{C}$. John et al. observed the dynamic mechanical and thermal properties of cyanate ester syntactic foams besides the nanoclay material [131]. The studies showed that a significant improvement in mechanical properties like tensile, flexural strength moduli was detected for the foams on the integration of nanoclay particles. Nanoclay hikes the toughness of the overall composite and, on the other hand, thermal properties are not much prejudiced by the addition of filler materials.

Maharsia et al. [132] studied mechanical properties in syntactic foams through nanoclay reinforcement. Results indicated that the presence of nanoclay ( $2 \%$ and $5 \%$ by weight) showed an improvement in mechanical properties though there was a reduction in modulus due to improper bonding between nanoclay particles and matrix material. Withers et al. [133] observed the effect of cloisite 25A montmorillonite (MMT) nanoclay filler material in epoxy-based composites. The nanocomposites were fabricated by varying the weight percentages of nanoparticles in it. According to the results, the optimum mechanical properties are shown at $2 \mathrm{wt} . \%$ of MMT clay addition. The improved surface properties are observed at the low percentage loadings of MMT clay particles. Mo-lin Chan et al. [134] studied the mechanism of reinforcement in nanoclay polymer composite. Different mechanical tests were conducted by varying the content of nanoparticles in the composite material. Interestingly the results are showed that tensile strength and modulus of the composite increased by $34 \%$ and $25 \%$ correspondingly. The establishment of limitations between the nanoclay clusters and epoxy resin can filter the matrix grains and additionally improve the strength of the composite. Some of the research publications on nanofillers in the composite materials are discussed in Table 14. 
Table 14. Various research publications on nanofillers in fiber composite materials.

\begin{tabular}{|c|c|c|c|}
\hline Fibers/Nanofillers & Polymer & Investigations & Reference \\
\hline Glass fibers/Silica & Epoxy resin & Elastic properties & [135] \\
\hline Pineapple/Silica & Epoxy resin & $\begin{array}{l}\text { Tensile fatigue } \\
\text { Fracture toughness }\end{array}$ & [136] \\
\hline Rubber/Silica & Epoxy resin & $\begin{array}{l}\text { Vibration and damping } \\
\text { Fracture toughness }\end{array}$ & [137] \\
\hline Glass/Kevlar/Silica & Epoxy resin & $\begin{array}{l}\text { Tensile strength } \\
\text { Flexural strength } \\
\text { Tensile strength }\end{array}$ & [138] \\
\hline Banana/Sisal/Glass/Redmud & Polyester resin & $\begin{array}{l}\text { Flexural strength } \\
\text { Impact strength }\end{array}$ & [139] \\
\hline Silica/Glass/Graphite & Polypropylene & Thermo Mechanical properties and elastic properties & [140] \\
\hline Basalt/Clay & Polypropylene & Impact Properties & [141] \\
\hline Carbon fiber/Carbon nanotube & Polyethylene & Mechanical properties & {$[142]$} \\
\hline Rubber/Carbon nanotube & - & Stress-strain analysis & [143] \\
\hline Carbon fiber/Carbon nanotube & - & Mechanical properties & [144] \\
\hline Bamboo/Clay & Polyvinyl alcohol & Thermal, Physical and mechanical properties & [145] \\
\hline $\begin{array}{c}\text { Pineapple/Carbon/Jute/Watermelon peel } \\
\text { nano particles form }\end{array}$ & Epoxy resin & Tensile, flexural and fracture toughness & {$[146]$} \\
\hline Sugar palm/Clay & Polyester & Thermal and mechanical properties & [147] \\
\hline Glass/Clay & Polyester & Mechanical properties & [148] \\
\hline Glass/Clay & Vinyl ester & Thermal and flame retardancy studies & [149] \\
\hline Glass/Silica & Vinyl ester & Mechanical properties & [150] \\
\hline Glass/Clay & Vinyl ester & Mechanical, thermal and vibration properties & [151-153] \\
\hline Glass/Clay & Vinyl ester & Mechanical properties & [154] \\
\hline Basalt/graphene oxide & Epoxy resin & $\begin{array}{l}\text { Interlaminar shear strength } \\
\text { Fracture toughness }\end{array}$ & [155] \\
\hline
\end{tabular}




\section{Applications}

Fiber-reinforced composites are better than pure polymer composites. There should be an occurrence of auxiliary applications on account of its high mechanical properties and lower expense. Due to an account of advanced properties, hybrid composites are a replacement for synthetic composites, particularly when it comes to the load-bearing and construction applications [24]. A recent study stated that goods made up of natural fiber composites have been increased and used in several applications such as ward boards, windows, car door panels, tables, packing selves and lightweight goods [156]. The utilization of natural fiber composites in place of synthetic and petroleum-based fiber composites has increased drastically in various sectors such as sports equipment, aerospace, office machinery, automobile, and shipping industries are one of the main application sectors for lightweight composite materials. The researchers found interest in the replacement of bio fiber-based composites due to its abundance, cost-effectiveness, recyclability, ecofriendliness, low fabrication cost and biodegradability $[157,158]$.

A recent survey stated that the fabrication of fiber-reinforced polymer composites has become more popular in commercial applications, especially in the aerospace industry. The utilization of fiber-based composite caused a reduction in overall weight by $35 \%$ of the aircraft, and shows a positive effect on fuel consumption and efficiency of the overall performance. Due to these properties, aircraft industries such as Boeing, Dreamliner and Airbus companies have started using the composites in the majority of their components [159]. The main crucial factor in composite fabrication is weight reduction. Some of the natural fibers serve as a natural filler material in the composite fabrication in the presence of bio-based and biodegradable matrix material designed for the extrusion film blowing of thin packages [160].

Santos da luz et al. worked on natural fiber composites in the replacement of synthetic fiber composites for military applications [161]. They compared natural fiber (pineapple) epoxy composite material and synthetic (aramid) fiber composite material in a hard armor. Results showed that the armor plate made from natural fibers has a stronger impact strength than synthetic fiber plates. Natural fiber hybrid nanocomposites are used in various industries because of its improvement in mechanical, thermal and moisture absorption along with light weight and less cost. Nowadays, these composites are in construction, biomedical, filtration, drug delivery, tissue template, wound dressing and cosmetics. Some of the potential applications are listed below [162].

1. Filter media: Liquid, gas and molecule filtration.

2. Nano-sensors: Biochemical, thermal and piezoelectric sensor.

3. Cosmetics: Skin cleaning and healing.

4. Life science: Drug delivery carrier and wound dressing.

5. Tissue engineering scaffolding: Porous membrane for skin, 3D scaffolds for bone and cartilage regeneration.

6. Industrial applications: Micro/nano electronic devices, electrostatic dissipation, LCD devices, lightweight space craft materials.

\section{Conclusions and Future Work}

In this review paper, fiber-based hybrid composites have been evaluated, specifically on account of their properties such as surface morphology, thermal stability, dynamic mechanical, mechanical, moisture absorption, fire retardance and applications. Hybridization became famous, not just because of the improved presentation of the subsequent items, but also due to the possibility of conquering the confinements that hamper the relevance of common filaments in specialized structures. There is an immense chance that a huge level of natural fibers can be consolidated in ordinary engineered fortified composites items, which is a major advance from biological and affordable perspectives. The quality natural fibers rely on the development conditions and development time affects the performance of the composite. Although there are so many advantages to using natural fibers in commercial 
applications, it is bounded to some of the applications because of its biodegradability and flammable properties compared to synthetic fiber composites. To overcome this problem, the researchers started to work on chemical treatment of natural fibers under various conditions. These modifications improved the fiber strength and also bonding capacity between matrix and reinforcement. On the other hand, the researchers found an interest in the integration of nanofillers into composite materials. The addition of nanoparticles to the hybrid composites played a crucial role in advancing their properties. The surface properties, fracture toughness, void elimination, amount of water absorbed is decreased and the dynamic mechanical properties are increased because of these nanofiller materials in the hybrid composite. It is worth saying that hybrid composite materials bring a revolution in the real-life commercial applications such as biomedical, aerospace, shipping industry, automobile, biomedical, construction, drug delivery, wound dressing and gas filtration applications. In the future, the alterations in fabrication techniques and the addition of nanofillers may lead to improvement as well as prediction of the results is possible, which attracts researchers to use it in multiple applications.

Author Contributions: Conceptualization, A.A.; methodology, A.A. and A.P.; investigation, A.A.; resources, A.V.; writing—original draft preparation, A.A.; writing—review and editing, G.J.; visualization, A.A.; supervision, A.P. and G.J.; project administration, G.J. All authors have read and agreed to the published version of the manuscript.

Funding: This research was funded by a grant (No. S-MIP-19-43) from the Research Council of Lithuania.

Conflicts of Interest: The authors declare no conflict of interest.

\section{References}

1. Megahed, M.; Abo-bakr, R.M.; Mohamed, S.A. Optimization of hybrid natural laminated composite beams for a minimum weight and cost design. Compos. Struct. 2020, 239, 111984. [CrossRef]

2. Wambua, P.; Ivens, J.; Verpoest, I. Natural fibers: Can they replace glass in fiber reinforced plastics. Compos. Sci. Technol. 2003, 63, 1259-1264. [CrossRef]

3. Rajak, D.K.; Pagar, D.D.; Menezes, P.L.; Linul, E. Fiber-Reinforced Polymer Composites: Manufacturing, properties, and applications. Polymers 2019, 11, 1667. [CrossRef] [PubMed]

4. Saba, N.; Paridah, M.T.; Abdan, K.; Ibrahim, N.A. Dynamic mechanical properties of oil palm nano filler/kenaf/epoxy hybrid nanocomposites. Constr. Build. Mater. 2016, 124, 133-138. [CrossRef]

5. Ahmad, F.; Choi, H.S.; Park, M.K. A review: Natural fiber composites selection in view of mechanical, light weight and economic properties. Macromol. Mater. Eng. 2015, 300, 10-24. [CrossRef]

6. Kiruthika, A.V. A review on physico-mechanical properties of bast fibre reinforced polymer composites. J. Build. Eng. 2017, 9, 91-99. [CrossRef]

7. George, J.; Sreekala, M.S.; Thomas, S. A review on interface modification and characterization of natural fiber reinforced plastic composites. Polym. Eng. Sci. 2001, 41, 1471-1485. [CrossRef]

8. Faruk, O.; Bledzki, A.K.; Fink, H.P.; Sain, M. Biocomposites reinforced with natural fibers: 2000-2010. Prog. Polym. Sci. 2012, 37, 1552-1596. [CrossRef]

9. Biswas, B.; Kandola, B.K. The effect of chemically reactive type flame retardant additives on flammability of PES toughened epoxy resin and carbon fiber-reinforced composites. Polym. Adv. Technol. 2011, 22, 1192-1204. [CrossRef]

10. John, M.J.; Anandjiwala, R.D. Recent developments in chemical modification and characterization of natural fiber-reinforced composites. Polym. Compos. 2008, 29, 187-207. [CrossRef]

11. Galos, J. Thin-ply composite laminates: A review. Compos. Struct. 2020, 236, 111920. [CrossRef]

12. Grefe, H.; Kandula, M.W.; Dilger, K. Influence of the fibre orientation on the lap shear strength and fracture behavior of adhesively bonded composite metal joints at high strain rates. Int. J. Adhes. Adhes. 2020, 97, 102486. [CrossRef]

13. Ou, Y.; Gattas, J.M.; Fernando, D.; Torero, J.L. Experimental investigation of a timber-concrete floor panel system with a hybrid glass fibre reinforced polymer-timber corrugated core. Eng. Struct. 2020, 203, 109832. [CrossRef]

14. Mishra, S.; Mohanty, A.K.; Drzal, L.T.; Misra, M.; Parija, S.; Nayak, S.K.; Tripathy, S.S. Studies on mechanical performance of biofibre/glass reinforced polyester hybrid composites. Compos. Sci. Technol. 2003, 63, 1377-1385. [CrossRef] 
15. Jawaid, M.; Abdul Khalil, H.P.S. Cellulosic/synthetic fibre reinforced polymer hybrid composites: A review. Carbohydr. Polym. 2011, 86, 1-18. [CrossRef]

16. John, M.J.; Thomas, S. Biofibres and biocomposites. Carbohydr. Polym. 2008, 71, 343-364. [CrossRef]

17. Bhoopathi, R.; Ramesh, M.; Deepa, C. Fabrication and property evaluation of banana-hemp-glass fiber reinforced composites. Procedia Eng. 2014, 97, 2032-2041. [CrossRef]

18. Alavudeen, A.; Rajini, N.; Karthikeyan, S.; Thiruchitrambalam, M.; Venkateshwaren, N. Mechanical properties of banana/kenaf fiber-reinforced hybrid polyester composites: Effect of woven fabric and random orientation. Mater. Des. 2015, 66, 246-257. [CrossRef]

19. Ramesh, M.; Palanikumar, K.; Reddy, K.H. Mechanical property evaluation of sisal-jute-glass fiber reinforced polyester composites. Compos. Part B 2013, 48, 1-9. [CrossRef]

20. Almeida Junior, J.H.S.; Amico, S.C.; Botelho, E.C.; Amado, F.D.R. Hybridization effect on the mechanical properties of curaua/glass fiber composites. Compos. Part B 2013, 55, 492-497. [CrossRef]

21. Velmurugan, R.; Manikandan, V. Mechanical properties of palmyra/glass fiber hybrid composites. Compos. Part A Appl. Sci. Manuf. 2007, 38, 2216-2226. [CrossRef]

22. Kumar, A.; Singh, R.C.; Chaudhary, R. Recent progress in production of metal matrix composites by stir casting process-An overview. Mater. Today Proc. 2020, 21, 1453-1457. [CrossRef]

23. Rajak, D.K.; Pagar, D.D.; Kumar, R.; Pruncu, C.I. Recent progress of reinforcement materials: A comprehensive overview of composite materials. J. Mater. Res. Technol. 2019, 8, 6354-6374. [CrossRef]

24. Sharma, A.K.; Bhandari, R.; Aherwar, A.; Rimasauskiene, R. Matrix materials used in composites: A comprehensive study. Mater. Today Proc. 2020, 21, 1559-1562. [CrossRef]

25. Bharath, K.N.; Basavarajappa, S. Applications of biocomposite materials based on natural fibers from renewable resources: A review. Sci. Eng. Compos. Mater. 2016, 23, 123-133. [CrossRef]

26. Djafari Petroudy, S.R. 3-Physical and mechanical properties of natural fibers. Adv. High Strength Nat. Fibre Compos. Constr. 2017, 59-83. [CrossRef]

27. Mohanty, A.K.; Misra, M.; Hinrichsen, G. Biofibres, biodegradable polymers and biocomposites: An overview. Macromol. Mater. Eng. 2000, 276, 1-24. [CrossRef]

28. Gholampour, A.; Ozbakkaloglu, T. A review of natural fiber composites: Properties, modification and processing techniques, characterization, applications. J. Mater. Sci. 2020, 55, 829-892. [CrossRef]

29. Wang, X.; Xie, J.; Zhang, H.; Zhang, W.; An, S.; Chen, S.; Luo, C. Determining the lignin distribution in plant fiber cell walls based on chemical and biological methods. Cellulose 2016, 26, 4241-4252. [CrossRef]

30. Sood, M.; Dwivedi, G. Effect of fiber treatment on flexural properties of natural fiber reinforced composites: A review. Egypt. J. Pet. 2018, 27, 775-783. [CrossRef]

31. Li, X.; Tabil, L.G.; Panigrahi, S. Chemical treatments of natural fiber for use in natural fiber-reinforced composites: A review. J. Polym. Environ. 2007, 15, 25-33. [CrossRef]

32. Mohanty, A.K.; Misra, M.; Drzal, L.T. Surface modifications of natural fibers and performance of the resulting biocomposites: An overview. Compos. Interfaces 2001, 8, 313-343. [CrossRef]

33. Ray, D.; Sarkar, B.K.; Rana, A.K.; Bose, N.R. Effect of alkali treated jute fibres on composite properties. Bull. Mater. Sci. 2001, 24, 129-135. [CrossRef]

34. Mishra, S.; Misra, M.; Tripathy, S.S.; Nayak, S.K.; Mohanty, A.K. Graft Copolymerization of Acrylonitrile on Chemically Modified Sisal Fibers. Macromol. Mater. Eng. 2001, 286, 107-113. [CrossRef]

35. Ali, A.; Shaker, K.; Nawab, Y.; Jabbar, M.; Hussain, T.; Militky, J.; Baheti, V. Hydrophobic treatment of natural fibers and their composites-A review. J. Ind. Text. 2018, 47, 2153-2183. [CrossRef]

36. Rong, M.Z.; Zhang, M.Q.; Liu, Y.; Yang, G.C.; Zeng, H.M. The effect of fiber treatment on the mechanical properties of unidirectional sisal-reinforced epoxy composites. Compos. Sci. Technol. 2001, 61, 1437-1447. [CrossRef]

37. Kumar, R.; Obrai, S.; Sharma, A. Chemical modifications of natural fiber for composite material. Pelagia Res. Libr. 2011, 2, 219-228.

38. Valadez-Gonzalez, A.; Cervantes-Uc, J.M.; Olayo, R.; Herrera-Franco, P.J. Effect of fiber surface treatment on the fiber-matrix bond strength of natural fiber reinforced composites. Compos. Part B Eng. 1999, 30, 309-320. [CrossRef]

39. Joseph, P.V.; Mathew, G.; Joseph, K.; Groeninckx, G.; Thomas, S. Dynamic mechanical properties of short sisal fibre reinforced polypropylene composites. Compos. Part A Appl. Sci. Manuf. 2003, 34, 275-290. [CrossRef] 
40. Idicula, M.; Malhotra, S.K.; Joseph, K.; Thomas, S. Dynamic mechanical analysis of randomly oriented intimately mixed short banana/sisal hybrid fibre reinforced polyester composites. Compos. Sci. Technol. 2005, 65, 1077-1087. [CrossRef]

41. Paul, S.; Nanda, P.; Gupta, R. PhCOCI-Py/basic alumina as a versatile reagent for benzoylation in solvent-free conditions. Molecules 2003, 8, 374-380. [CrossRef]

42. Pinem, J.A.; Wardani, A.K.; Aryanti, P.T.P.; Khoiruddin, K.; Wenten, I.G. Hydrophilic Modification of Polymeric Membrane using Graft Polymerization Method: A Mini Review. IOP Conf. Ser. Mater. Sci. Eng. 2019, 547, 1-12. [CrossRef]

43. Park, J.M.; Quang, S.T.; Hwang, B.S.; DeVries, K.L. Interfacial evaluation of modified Jute and Hemp fibers/polypropylene (PP)-maleic anhydride polypropylene copolymers (PP-MAPP) composites using micromechanical technique and nondestructive acoustic emission. Compos. Sci. Technol. 2006, 66, 2686-2699. [CrossRef]

44. Mohanty, S.; Nayak, S.K.; Verma, S.K.; Tripathy, S.S. Effect of MAPP as a Coupling Agent on the Performance of Jute-PP Composites. J. Reinf. Plast. Compos. 2004, 23, 625-637. [CrossRef]

45. Sreekala, M.S.; Kumaran, M.G.; Joseph, S.; Jacob, M.; Thomas, S. Oil palm fibre reinforced phenol formaldehyde composites: Influence of fibre surface modifications on the mechanical performance. Appl. Compos. Mater. 2000, 7, 295-329. [CrossRef]

46. Suwanruji, P.; Tuechart, T.; Smitthipong, W.; Chollakup, R. Modification of pineapple leaf fiber surfaces with silane and isocyanate for reinforcing thermoplastic. J. Thermoplast. Compos. Mater. 2017, 30, 1344-1360. [CrossRef]

47. Shih, Y.F.; Chang, W.C.; Liu, W.C.; Lee, C.C.; Kuan, C.S.; Yu, Y.H. The inclusion of PALF made the thermoplastic matrix stiffer, especially for the LDPE composites. J. Taiwan Inst. of Chem. Eng. 2014, 45, 2039-2046. [CrossRef]

48. Sanjay, M.R.; Madhu, P.; Jawaid, M.; Senthamaraikannan, P.; Senthil, S.; Pradeep, S. Characterization and properties of natural fiber polymer composites: A comprehensive review. J. Clean. Prod. 2018, 172, 566-581. [CrossRef]

49. Fei, M.E.; Xie, T.; Liu, W.; Chen, H.; Qiu, R. Surface grafting of bamboo fibers with 1,2-epoxy4-vinylcyclohexane for reinforcing unsaturated polyester. Cellulose 2017, 24, 5505-5514. [CrossRef]

50. Seki, Y. Innovative multifunctional siloxane treatment of jute fiber surface and its effect on the mechanical properties of jute/thermoset composites. Mater. Sci. Eng. A 2009, 508, 247-252. [CrossRef]

51. Jarukumjorn, K.; Suppakarn, N. Effect of glass fiber hybridization on properties of sisal fiber-polypropylene composites. Compos. Part B Eng. 2009, 40, 623-627. [CrossRef]

52. Schmidt, T.M.; Goss, T.M.; Amico, S.C.; Lekakou, C. Permeability of hybrid reinforcements and mechanical properties of their composites molded by resin transfer molding. J. Reinf. Plast. Compos. 2009, 38, 2839-2850. [CrossRef]

53. Nayak, S.K.; Mohanty, S.; Samal, S.K. Influence of short bamboo/glass fiber on the thermal, dynamic mechanical and rheological properties of polypropylene hybrid composites. Mater. Sci. Eng. A 2009, 523, 32-38. [CrossRef]

54. Vega-Hernández, M.A.; Rosas-Aburto, A.; Vivaldo-Lima, E.; Vázquez-Torres, H.; Cano-Díaz, G.S.; Pérez-Salinas, P.; Hernández-Luna, M.G.; Alcaraz-Cienfuegos, J.; Zolotukhin, M.G. Development of polystyrene composites based on blue agave bagasse by in situ RAFT polymerization. J. Appl. Polym. Sci. 2019, 136, 47089. [CrossRef]

55. Haneefa, A.; Bindu, P.; Aravind, I.; Thomas, S. Studies on tensile and flexural properties of short banana/glass hybrid fiber reinforced polystyrene composites. J. Compos. Mater. 2008, 42, 1471-1489. [CrossRef]

56. Hao, X.; Zhou, H.; Mu, B.; Chen, L.; Guo, Q.; Yi, X.; Sun, L.; Wang, Q.; Ou, R. Effects of fiber geometry and orientation distribution on the anisotropy of mechanical properties, creep behavior and thermal expansion of natural fiber/HDPE composites. Compos. Part B Eng. 2020, 185, 107778. [CrossRef]

57. Robledo-Ortíz, J.R.; González-López, M.E.; Rodrigue, D.; Gutiérrez-Ruiz, J.F.; Prezas-Lara, F.; Pérez-Fonseca, A.A. Improving the Compatibility and Mechanical Properties of Natural Fibers/Green Polyethylene Biocomposites Produced by Rotational Molding. J. Polym. Environ. 2020, 28, 1040-1049. [CrossRef] 
58. Paran, S.M.R.; Naderi, G.; Shokoohi, S.; Ebadati, J.; Dubois, C. Mechanical and Thermal Properties of Green Thermoplastic Elastomer Vulcanizate Nanocomposites Based on Poly (vinyl chloride) and Nitrile Butadiene Rubber Containing Organoclay and Rice Straw Natural Fibers. J. Polym. Environ. 2019, 27, 2017-2026. [CrossRef]

59. Ji, B.; Gao, H. Mechanical properties of nanostructure of biological materials. J. Mech. Phys. Solids 2004, 52, 1963-1990. [CrossRef]

60. Zare, Y.; Garmabi, H. A developed model to assume the interphase properties in a ternary polymer nanocomposite reinforced with two nanofillers. Compos. Part B Eng. 2015, 75, 29-35. [CrossRef]

61. Boussehel, H.; Mazouzi, D.E.; Belghar, N.; Guerira, B.; Lachi, M. Effect of chemicals treatments on the morphological, mechanical, thermal and water uptake properties of polyvinyl chloride/palm fibers composites. Rev. Compos. Mater. Av. 2019, 29, 1-8. [CrossRef]

62. Ihamouchen, C.; Djidjelli, H.; Boukerrou, A.; Krim, S.; Kaci, M.; Martinez, J.J. Effect of surface treatment on the physicomechanical and thermal properties of high-density polyethylene/olive husk flour composites. J. Appl. Polym. Sci. 2012, 123, 1310-1319. [CrossRef]

63. Kaci, M.; Djidjelli, H.; Boukerrou, A.; Zaidi, L. Effect of wood filler treatment and EBAGMA compatibilizer on morphology and mechanical properties of low-density polyethylene/olive husk flour composites. Express Polym. Lett. 2007, 1, 467-473. [CrossRef]

64. Haseena, A.P.; Dasan, K.P.; Namitha, R.; Unnikrishna, G.; Thomas, S.A. Investigation on interfacial adhesion of short sisal/coir hybrid fibre reinforced natural rubber composites by restricted equilibrium swelling technique. Compos. Interfaces 2004, 11, 489-513. [CrossRef]

65. Prasantha Kumar, R.; Thomas, S. Interfacial adhesion in sisal fiber/SBR composites: An investigation by the restricted equilibrium swelling technique. J. Adhes. Sci. Technol. 2001, 15, 633-652. [CrossRef]

66. Sari, P.S.; Thomas, S.; Spatenka, P.; Ghanam, Z.; Jenikova, Z. Effect of plasma modification of polyethylene on natural fibre composites prepared via rotational moulding. Compos. Part B Eng. 2019, 177, 107344. [CrossRef]

67. Boran Torun, S.; Pesman, E.; Donmez Cavdar, A. Effect of alk ali treatment on composites made from recycled polyethylene and chestnut cupula. Polym. Compos. 2019, 40, 4442-4451. [CrossRef]

68. Salazar, M.A.H.; Aguirre, J.P.C.; Navarro, S.G.; Blay, L.R. Injection molding of coir coconut fiber reinforced polyolefin blends: Mechanical, viscoelastic, thermal behavior and three-dimensional microscopy study. Polymers 2020, 12, 1507. [CrossRef]

69. Rahman, H.; Alimuzzaman, S.; Sayeed, M.M.A.; Khan, R.A. Effect of gamma radiation on mechanical properties of pineapple leaf fiber (PALF)-reinforced low-density polyethylene (LDPE) composites. Int. J. Plast. Technol. 2019, 23, 229-238. [CrossRef]

70. Sahadat Hossain, M.; Razzak, M.; Uddin, M.B.; Chowdhury, A.M.S.; Khan, R.A. Physico-mechanical properties of jute fiber-reinforced LDPE-based composite: Effect of disaccharide (sucrose) and gamma radiation. Radiat. Eff. Defects Solids 2019, 175, 516-528. [CrossRef]

71. Sayem, A.S.M.; Haider, J.; Sayeed, M.A. Development and characterisation of multi-layered jute fabric-reinforced HDPE composites. J. Compos. Mater. 2019, 54, 1831-1845. [CrossRef]

72. Essabir, H.; Boujmal, R.; Bensalah, M.O.; Rodrigue, D.; Bouhfid, R.; Qaiss, A.E.K. Mechanical and thermal properties of hybrid composites: Oil-palm fiber/clay reinforced high density polyethylene. Mech. Mater. 2016, 98, 36-43. [CrossRef]

73. Nayak, S.; Kumar Khuntia, S. Development and study of properties of Moringa oleifera fruit fibers/polyethylene terephthalate composites for packaging applications. Compos. Commun. 2019, 15, 113-119. [CrossRef]

74. Ahmad, M.A.A.; Abdul Majid, M.S.; Ridzuan, M.J.M.; Mazlee, M.N.; Gibson, A.G. Dynamic mechanical analysis and effects of moisture on mechanical properties of interwoven hemp/polyethylene terephthalate (PET) hybrid composites. Constr. Build. Mater. 2018, 179, 265-276. [CrossRef]

75. Antich, P.; Vázquez, A.; Mondragon, I.; Bernal, C. Mechanical behavior of high impact polystyrene reinforced with short sisal fibers. Compos. Part A Appl. Sci. Manuf. 2006, 37, 139-150. [CrossRef]

76. Andrzejewski, J.; Misra, M.; Mohanty, A.K. Polycarbonate biocomposites reinforced with a hybrid filler system of recycled carbon fiber and biocarbon: Preparation and thermomechanical characterization. J. Appl. Polym. Sci. 2018, 135, 46449. [CrossRef] 
77. Feng, N.L.; Malingam, S.D.; Ping, C.W.; Razali, N. Mechanical properties and water absorption of kenaf/pineapple leaf fiber-reinforced polypropylene hybrid composites. Polym. Compos. 2019, 41, 1255-1264. [CrossRef]

78. Haris, A.; Kureemun, U.; Tran, L.Q.N.; Lee, H.P. Water Uptake and Its Effects on Mechanical and Acoustic Properties of flax/polypropylene Composite. J. Nat. Fibers 2019, 16, 1-15. [CrossRef]

79. Liu, L.; Wang, Z.; Yu, Y.; Fu, S.; Nie, Y.; Wang, H.; Song, P. Engineering Interfaces toward High-Performance Polypropylene/Coir Fiber Biocomposites with Enhanced Friction and Wear Behavior. ACS Sustain. Chem. Eng. 2019, 7, 18453-18462. [CrossRef]

80. Samal, S.K.; Mohanty, S.; Nayak, S.K. Banana/glass fiber-reinforced polypropylene hybrid composites: Fabrication and performance evaluation. Polym. Plast. Technol. Eng. 2009, 48, 397-414. [CrossRef]

81. Fang, Y.; Wang, Q.; Guo, C.; Song, Y.; Cooper, P.A. Effect of zinc borate and wood flour on thermal degradation and fire retardancy of Polyvinyl chloride (PVC) composites. J. Anal. Appl. Pyrolysis 2013, 100, 230-236. [CrossRef]

82. Bakshi, P.; Pappu, A.; Patidar, R.; Gupta, M.K.; Thakur, V.K. Transforming marble waste into high-performance, water resistant and thermally insulative hybrid polymer composites for environmental sustainability. Polymers 2020, 12, 1781. [CrossRef]

83. Bakare, F.O.; Skrifvars, M.; Åkesson, D.; Wang, Y.; Afshar, S.J.; Esmaeili, N. Synthesis and characterization of bio-based thermosetting resins from lactic acid and glycerol. J. Appl. Polym. Sci. 2014, 131, 1-9. [CrossRef]

84. Ail Mutar, M.; Attab, Z.H.A. Synthesis, Characterization and Properties of New Unsaturated Polyesters Resins Reinforced with Some Fillers (Carbon Nano, Nano TiO2, TiO2 and $\mathrm{ZnO}$ ) for Composite Application. Int. J. Appl. Nat. Sci. (IJANS) 2017, 6, 79-100.

85. Mohammad, N.A. Synthesis, Characterization and Properties of the New Unsaturated Polyester Resins for Composite Application. Master's Thesis, University Sains Malaysia, Penang, Malaysia, April 2017.

86. Yorseng, K.; Rangappa, S.M.; Pulikkalparambil, H.; Siengchin, S.; Parameswaranpillai, J. Accelerated weathering studies of kenaf/sisal fiber fabric reinforced fully biobased hybrid bioepoxy composites for semi-structural applications: Morphology, thermo-mechanical, water absorption behavior and surface hydrophobicity. Constr. Build. Mater. 2020, 235, 117464. [CrossRef]

87. Manalo, A.C.; Aravinthan, T.; Karunasena, W.; Islam, M.M. Flexural behaviour of structural fibre composite sandwich beams in flatwise and edgewise positions. Compos. Struct. 2010, 92, 984-995. [CrossRef]

88. Rwawiire, S.; Tomkova, B.; Militky, J.; Jabbar, A.; Kale, B.M. Development of a biocomposite based on green epoxy polymer and natural cellulose fabric (bark cloth) for automotive instrument panel applications. Compos. Part B Eng. 2015, 81, 149-157. [CrossRef]

89. Pandey, J.K.; Ahn, S.H.; Lee, C.S.; Mohanty, A.K.; Misra, M. Recent advances in the application of natural fiber-based composites. Macromol. Mater. Eng. 2010, 295, 975-989. [CrossRef]

90. Alves, J.L.C.; Prado, K.S.; De Paiva, J.M.F. Compressive and Interlaminar Shear Strength Properties of Biaxial Fibreglass Laminates Hybridized with Jute Fibre Produced by Vacuum Infusion. J. Nat. Fibers 2019, 16, 1-16. [CrossRef]

91. Asim, M.; Jawaid, M.; Paridah, M.T.; Saba, N.; Nasir, M.; Shahroze, R.M. Dynamic and thermo-mechanical properties of hybridized kenaf/PALF reinforced phenolic composites. Polym. Compos. 2019, 40, 3814-3822. [CrossRef]

92. Asim, M.; Paridah, M.T.; Saba, N.; Jawaid, M.; Alothman, O.Y.; Nasir, M.; Almutairi, Z. Thermal, physical properties and flammability of silane treated kenaf/pineapple leaf fibres phenolic hybrid composites. Compos. Struct. 2018, 202, 1330-1338. [CrossRef]

93. Liu, Y.; Wang, L.; Liu, D.; Ma, Y.; Tian, Y.; Tong, J.; Senthamaraikannan, P.; Saravanakumar, S. Evaluation of wear resistance of corn stalk fiber reinforced brake friction materials prepared by wet granulation. Wear 2019, 432-433, 102918. [CrossRef]

94. Singha, A.S.; Thakur, V.K. Synthesis and characterization of pine needles reinforced RF matrix based biocomposites. E-J. Chem. 2008, 5, 1055-1062. [CrossRef]

95. Singha, A.S.; Thakur, V.K. Mechanical, thermal and morphological properties of grewia optiva fiber polymer matrix composites. Polym.-Plast. Technol. Eng. 2009, 48, 201-208. [CrossRef]

96. Singha, A.S.; Thakur, V.K. fabrication and characterization of H. sabdariffa fiber reinforced green polymer composites. Polym. Plast. Technol. Eng. 2009, 48, 482-487. [CrossRef] 
97. Singha, A.S.; Thakur, V.K. Fabrication and characterization of S. cilliare fiber reinforced polymer composites. Bull. Mater. Sci. 2009, 32, 49-58. [CrossRef]

98. Atmakuri, A.; Palevicius, A.; Griskevicius, P.; Janušas, G. Investigation of mechanical properties of hemp and flax fibers hybrid composites for biomedical applications. Mechanika 2019, 25, 149-155. [CrossRef]

99. Soundhar, A.; Kandasamy, J. Mechanical, Chemical and Morphological Analysis of Crab shell/Sisal Natural Fiber Hybrid Composites. J. Nat. Fibers 2019, 16, 1-15. [CrossRef]

100. Aruchamy, K.; Pavayee Subramani, S.; Palaniappan, S.K.; Sethuraman, B.; Velu Kaliyannan, G. Study on mechanical characteristics of woven cotton/bamboo hybrid reinforced composite laminates. J. Mater. Res. Technol. 2020, 9, 718-726. [CrossRef]

101. Yang, Z.; Liu, J.; Wang, F.; Li, S.; Feng, X. Effect of fiber hybridization on mechanical performances and impact behaviors of basalt fiber/UHMWPE fiber reinforced epoxy composites. Compos. Struct. 2019, 229, 111434. [CrossRef]

102. Sarasini, F.; Tirillò, J.; Valente, M.; Valente, T.; Cioffi, S.; Iannace, S.; Sorrentino, L. Effect of basalt fiber hybridization on the impact behavior under low impact velocity of glass/basalt woven fabric/epoxy resin composites. Compos. Part A Appl. Sci. Manuf. 2013, 47, 109-123. [CrossRef]

103. Doddi, P.R.V.; Chanamala, R.; Dora, S.P. Dynamic mechanical properties of epoxy based PALF/basalt hybrid composite laminates. Mater. Res. Express 2019, 6, 105345. [CrossRef]

104. Balaji, A.; Sivaramakrishnan, K.; Karthikeyan, B.; Purushothaman, R.; Swaminathan, J.; Kannan, S.; Udhayasankar, R.; Madieen, A.H. Study on mechanical and morphological properties of sisal/banana/coir fiber-reinforced hybrid polymer composites. J. Braz. Soc. Mech. Sci. Eng. 2019, 41, 386. [CrossRef]

105. Naveen, J.; Jawaid, M.; Zainudin, E.S.; Sultan, M.T.H.; Yahaya, R. Mechanical and moisture diffusion behavior of hybrid Kevlar/Cocos nucifera sheath reinforced epoxy composites. J. Mater. Res. Technol. 2019, 8, 1308-1318. [CrossRef]

106. Al-Hajaj, Z.; Sy, B.L.; Bougherara, H.; Zdero, R. Impact properties of a new hybrid composite material made from woven carbon fibers plus flax fibers in an epoxy matrix. Compos. Struct. 2019, 208, 346-356. [CrossRef]

107. Prasad, L.; Saini, A.; Kumar, V. Mechanical Performance of Jute and Basalt Fiber Geo-grid-Reinforced Epoxy Hybrid Composite Material. J. Nat. Fibers 2019, 16, 1-11. [CrossRef]

108. Chee, S.S.; Jawaid, M.; Sultan, M.T.H.; Alothman, O.Y.; Abdullah, L.C. Evaluation of the hybridization effect on the thermal and thermo-oxidative stability of bamboo/kenaf/epoxy hybrid composites. J. Therm. Anal. Calorim. 2019, 137, 55-63. [CrossRef]

109. Srinivasan, V.S.; Rajendra Boopathy, S.; Sangeetha, D.; Vijaya Ramnath, B. Evaluation of mechanical and thermal properties of banana-flax based natural fibre composite. Mater. Des. 2014, 60, 620-627. [CrossRef]

110. Raja, T.; Anand, P. Evaluation of Thermal Stability and Thermal Properties of Neem/Banyan Reinforced Hybrid Polymer Composite. Mater. Perform. Charact. 2019, 8, 481-490. [CrossRef]

111. Rashid, A.H.A.; Ahmad, R.; Jaafar, M.; Roslan, M.N.; Ariffin, S. Mechanical properties evaluation of woven coir and kevlar reinforced epoxy composites. Adv. Mater. Res. 2011, 277, 36-42.

112. Anand, G.; Alagumurthi, N.; Elansezhian, R.; Venkateshwaran, N. Dynamic mechanical, thermal and wear analysis of Ni-P coated glass fiber $/ \mathrm{Al}_{2} \mathrm{O}_{3}$ nanowire reinforced vinyl ester composite. Alex. Eng. J. 2018, 57, 621-631. [CrossRef]

113. Fragassa, C.; Pavlovic, A.; Santulli, C. Mechanical and impact characterisation of flax and basalt fibre vinylester composites and their hybrids. Compos. Part B Eng. 2018, 137, 247-259. [CrossRef]

114. Almansour, F.A.; Dhakal, H.N.; Zhang, Z.Y. Investigation into Mode II interlaminar fracture toughness characteristics of flax/basalt reinforced vinyl ester hybrid composites. Compos. Sci. Technol. 2018, 154, 117-127. [CrossRef]

115. Almansour, F.A.; Dhakal, H.N.; Zhang, Z.Y. Effect of water absorption on Mode I interlaminar fracture toughness of flax/basalt reinforced vinyl ester hybrid composites. Compos. Struct. 2017, 168, 813-825. [CrossRef]

116. Fatinah, T.S.; Abdul Majid, M.S.; Ridzuan, M.J.M.; Hong, T.W.; Amin, N.A.M.; Afendi, M. Tensile properties of compressed moulded Napier/glass fibre reinforced epoxy composites. J. Phys. Conf. Ser. 2017, 908, 1-9. [CrossRef]

117. Akash, G.; Gupta, K.G.; Venkatesha Gupta, N.S.; Sreenivas Rao, K.V. A study on flammability and moisture absorption behavior of sisal/coir fiber reinforced hybrid composites. IOP Conf. Ser. Mater. Sci. Eng. 2017, 191, 012003. [CrossRef] 
118. Salleh, Z.; Taib, Y.M.; Hyie, K.M.; Mihat, M.; Berhan, M.N.; Ghani, M.A.A. Fracture toughness investigation on long kenaf/woven glass hybrid composite due to water absorption effect. Procedia Eng. 2012, 41, 1667-1673. [CrossRef]

119. Pappu, A.; Pickering, K.L.; Thakur, V.K. Manufacturing and characterization of sustainable hybrid composites using sisal and hemp fibres as reinforcement of poly (lactic acid) via injection moulding. Ind. Crops Prod. 2019, 137, 260-269. [CrossRef]

120. Rosamah, E.; Hossain, M.S.; Abdul Khalil, H.P.S.; Wan Nadirah, W.O.; Dungani, R.; Nur Amiranajwa, A.S.; Suraya, N.L.M.; Fizree, H.M.; Mohd Omar, A.K. Properties enhancement using oil palm shell nanoparticles of fibers reinforced polyester hybrid composites. Adv. Compos. Mater. 2017, 26, 259-272. [CrossRef]

121. Boccaccini, A.R.; Erol, M.; Stark, W.J.; Mohn, D.; Hong, Z.; Mano, J.F. Polymer/bioactive glass nanocomposites for biomedical applications: A review. Compos. Sci. Technol. 2010, 70, 1764-1776. [CrossRef]

122. Pappu, A.; Thakur, V.K. Towards sustainable micro and nano composites from fly ash and natural fibers for multifunctional applications. Vacuum 2017, 146, 375-385. [CrossRef]

123. Majeed, K.; Jawaid, M.; Hassan, A.A.B.A.A.; Bakar, A.A.; Khalil, H.A.; Salema, A.A.; Inuwa, I. Potential materials for food packaging from nanoclay/natural fibres filled hybrid composites. Mater. Des. 2013, 46, 391-410. [CrossRef]

124. Arrakhiz, F.Z.; Benmoussa, K.; Bouhfid, R.; Qaiss, A. Pine cone fiber/clay hybrid composite: Mechanical and thermal properties. Mater. Des. 2013, 50, 376-381. [CrossRef]

125. El-Sheikhy, R.; Al-Shamrani, M. Interfacial bond assessment of clay-polyolefin nanocomposites CPNC on view of mechanical and fracture properties. Adv. Powder Technol. 2017, 28, 983-992. [CrossRef]

126. Assaedi, H.; Shaikh, F.U.A.; Low, I.M. Effect of nano-clay on mechanical and thermal properties of geopolymer. J. Asian Ceram. Soc. 2016, 190, 19-28. [CrossRef]

127. Hakamy, A.; Shaikh, F.U.A.; Low, I.M. Effect of calcined nanoclay on microstructural and mechanical properties of chemically treated hemp fabric-reinforced cement nanocomposites. Constr. Build. Mater. 2015, 33, 395-399. [CrossRef]

128. Eesaee, M.; Shojaei, A. Effect of nanoclays on the mechanical properties and durability of novolac phenolic resin/woven glass fiber composite at various chemical environments. Compos. Part A Appl. Sci. Manuf. 2014, 63, 149-158. [CrossRef]

129. Ávila, A.F.; Morais, D.T.S. Modeling nanoclay effects into laminates failure strength and porosity. Compos. Struct. 2009, 87, 55-62. [CrossRef]

130. Binu, P.P.; George, K.E.; Vinodkumar, M.N. Effect of Nanoclay, Cloisite15A on the Mechanical Properties and Thermal Behavior of Glass Fiber Reinforced Polyester. Procedia Technol. 2016, 25, 843-853. [CrossRef]

131. John, B.; Nair, C.P.R.; Ninan, K.N. Effect of nanoclay on the mechanical, dynamic mechanical and thermal properties of cyanate ester syntactic foams. Mater. Sci. Eng. A 2010, 527, 5435-5443. [CrossRef]

132. Maharsia, R.R.; Jerro, H.D. Enhancing tensile strength and toughness in syntactic foams through nanoclay reinforcement. Mater. Sci. Eng. A 2007, 454, 416-422. [CrossRef]

133. Withers, G.J.; Yu, Y.; Khabashesku, V.N.; Cercone, L.; Hadjiev, V.G.; Souza, J.M.; Davis, D.C. Improved mechanical properties of an epoxy glass-fiber composite reinforced with surface organomodified nanoclays. Compos. Part B Eng. 2015, 72, 175-182. [CrossRef]

134. Chan, M.L.; Lau, K.T.; Wong, T.T.; Ho, M.P.; Hui, D. Mechanism of reinforcement in a nanoclay/polymer composite. Compos. Part B Eng. 2011, 42, 1708-1712. [CrossRef]

135. Hassanzadeh-Aghdam, M.K.; Ansari, R.; Mahmoodi, M.J. Micromechanical analysis of the elastic response of glass-epoxy hybrid composites containing silica nanoparticles. Mech. Adv. Mater. Struct. 2019, 26, 1920-1934. [CrossRef]

136. Dinesh, T.; Kadirvel, A.; Hariharan, P. Role of nano-silica in tensile fatigue, fracture toughness and low-velocity impact behaviour of acid-treated pineapple fibre/stainless steel wire mesh-reinforced epoxy hybrid composite. Mater. Res. Express 2019, 6, 109-127. [CrossRef]

137. Huang, C.Y.; Tsai, J.L. Characterizing vibration damping response of composite laminates containing silica nanoparticles and rubber particles. J. Compos. Mater. 2015, 49, 545-557. [CrossRef]

138. Gokuldass, R.; Ramesh, R. Mechanical Strength Behavior of Hybrid Composites Tailored by Glass/Kevlar Fibre-Reinforced in Nano-Silica and Micro-Rubber Blended Epoxy. Silicon 2019, 11, 2731-2739. [CrossRef]

139. Prabu, V.A.; Kumaran, S.T.; Uthayakumar, M.; Manikandan, V. Influence of redmud particle hybridization in banana/sisal and sisal/glass composites. Part. Sci. Technol. 2018, 36, 402-407. [CrossRef] 
140. Pedrazzoli, K.D.; Pegoretti, A. Hybridization of short glass fiber polypropylene composites with nanosilica and graphite nanoplatelets. J. Reinf. Plast. Compos. 2014, 33, 1682-1695. [CrossRef]

141. Reza Khalili, S.M.; Farsani, R.E.; Soleimani, N.; Hedayatnasab, Z. Charpy impact behavior of clay/basalt fiber-reinforced polypropylene nanocomposites at various temperatures. J. Thermoplast. Compos. Mater. 2014, 29, 1416-1428. [CrossRef]

142. Ahmadi, M.; Ansari, R.; Rouhi, S. Fracture behavior of the carbon nanotube/carbon fiber/polymer multiscale composites under bending test-A stochastic finite element method. Mech. Adv. Mater. Struct. 2019, 26, 1169-1177. [CrossRef]

143. Georgantzinos, S.K.; Giannopoulos, G.I.; Anifantis, N.K. Investigation of stress-strain behavior of single walled carbon nanotube/rubber composites by a multi-scale finite element method. Theor. Appl. Fract. Mech. 2009, 52, 158-164. [CrossRef]

144. Malekimoghadam, R.; Icardi, U. Prediction of mechanical properties of carbon nanotube-carbon fiber reinforced hybrid composites using multi-scale finite element modelling. Compos. Part B Eng. 2019, 177, 107405. [CrossRef]

145. Adamu, M.; Rahman, M.R.; Hamdan, S. Formulation optimization and characterization of bamboo/polyvinyl alcohol/clay nanocomposite by response surface methodology. Compos. Part B Eng. 2019, 176, 107297. [CrossRef]

146. Balakrishnan, S.; Krishnaraj, C.; Raajeshkrishna, C.R. Mechanical characterization of pineapple, watermelon peel nanoparticles reinforced carbon, jute fabric and its hybrid epoxy composites. Mater. Res. Express 2019, 6, 2053-2062. [CrossRef]

147. Shahroze, R.M.; Ishak, M.R.; Salit, M.S.; Leman, Z.; Chandrasekar, M.; Munawar, N.S.; Asim, M. Sugar palm fiber/polyester nanocomposites: Influence of adding nanoclay fillers on thermal, dynamic mechanical and physical properties. J. Vinyl Addit. Technol. 2019, 26, 236-243. [CrossRef]

148. Jawahar, P.; Balasubramanian, M. Influence of nanosize clay platelets on the mechanical properties of glass fiber reinforced polyester composites. J. Nanosci. Nanotechnol. 2006, 6, 3973-3981. [CrossRef]

149. Zhu, H.G.; Liu, M.Y.; Yuen, R.K.; Leung, C.K.; Kim, J.K. Thermal performance and flame retardancy studies of vinyl ester and glass fiber reinforced plastic composites containing nanoclay. J. Compos. Mater. 2014, 48, 165-177. [CrossRef]

150. Shaker, K.; Nawab, Y.; Saouab, A.; Ashraf, M.; Khan, A.N. Effect of silica particle loading on shape distortion in glass/vinyl ester-laminated composite plates. J. Text. Inst. 2018, 109, 656-664. [CrossRef]

151. Chandradass, J.; Ramesh Kumar, M.; Velmurugan, R. Effect of clay dispersion on mechanical, thermal and vibration properties of glass fiber-reinforced vinyl ester composites. J. Reinf. Plast. Compos. 2008, 27, 1585-1601. [CrossRef]

152. Raghavendra, N.; Murthy, H.N.; Mahesh, K.V.; Mylarappa, M.; Ashik, K.P.; Siddeswara, D.M.K.; Krishna, M. Effect of nanoclays on the performance of mechanical, thermal and flammability of Vinylester based nanocomposites. Mater. Today Proc. 2017, 4, 12109-12117. [CrossRef]

153. Hussain, F.; Dean, D.; Haque, A.; Shamsuzzoha, A.M. S2-Glass/vinylester polymer nanocomposites: Manufacturing, structures, thermal and mechanical properties. J. Adv. Mater. 2005, 37, 16-27.

154. Park, J.Y.; Zureick, A.H. Effect of filler and void content on mechanical properties of pultruded composite materials under shear loading. Polym. Compos. 2005, 26, 181-192. [CrossRef]

155. Kim, S.H.; Park, S.J. Effect of graphene oxide on interfacial interactions and fracture toughness of basalt fiber-reinforced epoxy composites. J. Nanosci. Nanotechnol. 2020, 20, 6760-6767. [CrossRef]

156. Shalwan, A.; Yousif, B.F. In state of art: Mechanical and tribological behaviour of polymeric composites based on natural fibres. Mater. Des. 2013, 48, 14-24. [CrossRef]

157. Alkbir, M.F.M.; Sapuan, S.M.; Nuraini, A.A.; Ishak, M.R. Fibre properties and crashworthiness parameters of natural fibre-reinforced composite structure: A literature review. Compos. Struct. 2016, 9, 59-73. [CrossRef]

158. Yang, Y.; Boom, R.; Irion, B.; Van Heerden, D.J.; Kuiper, P.; Wit, H. Recycling of composite materials. Chem. Eng. Process. Process Intensif. 2012, 51, 53-68. [CrossRef]

159. Schiffman, J.D.; Schauer, C.L. A review: Electrospinning of biopolymer nanofibers and their applications. Polym. Rev. 2008, 48, 317-352. [CrossRef]

160. Kharrat, F.; Khlif, M.; Hilliou, L.; Haboussi, M.; Covas, J.A.; Nouri, H.; Bradai, C. Minimally processed date palm (Phoenix dactylifera L.) leaves as natural filler and processing aids in poly (lactic acid) composites designed for the extrusion film blowing of thin packages. Ind. Crops Prod. 2020, 154, 112637. [CrossRef] 
161. Luz, F.S.D.; Garcia Filho, F.D.C.; Oliveira, M.S.; Nascimento, L.F.C.; Monteiro, S.N. Composites with natural fibers and conventional materials applied in a hard armor: A comparison. Polymers 2020, 12, 1920. [CrossRef]

162. Huang, Z.M.; Zhang, Y.Z.; Kotaki, M.; Ramakrishna, S. A review on polymer nanofibers by electrospinning and their applications in nanocomposites. Compos. Sci. Technol. 2003, 63, 2223-2253. [CrossRef] 